This work is licensed under a Creative Commons Attribution 3.0 License.

\title{
A new genus and two new species of cavernicolous amphipods (Crustacea: Typhlogammaridae) from the Western Caucasus
}

\author{
Dmitry A. SIDOROV ${ }^{1 *}$, Andrey A. GONTCHAROV ${ }^{2} \&$ Svetlana N. SHARINA $^{3}$ \\ ${ }^{1,2}$ Institute of Biology and Soil Science, Far Eastern Branch of the Russian Academy of Sciences, \\ 100-let Vladivostoku Av. 159, Vladivostok 690022, Russia. \\ ${ }^{3}$ A.V. Zhirmunsky Institute of Marine Biology, Far Eastern Branch of the Russian Academy \\ of Sciences, 17 Palchevskogo St., Vladivostok 690041, Russia. \\ ${ }^{3}$ Far Eastern Federal University, 8 Suhanova St., Vladivostok 690950, Russia. \\ *Corresponding author: biospeorossica@gmail.com \\ ${ }^{1}$ urn:Isid:zoobank.org:author:CA39E974-5B23-42CE-919D-5EC937301494 \\ ${ }^{2}$ urn:Isid:zoobank.org:author:D16C97A5-FB70-414A-ACCE-D17519A1BE6C \\ ${ }^{3}$ urn:lsid:zoobank.org:author:3159D4D5-2BF1-4E12-8280-2BD3F83C8F55
}

\begin{abstract}
This study deals with the biodiversity and distribution of cavernicolous Amphipoda in caves of the Arabika massif (Western Caucasus). The Sarma, Trojka and Orlinoe Gnezdo caves were explored during speleological expeditions over the years 2011-12. Two new species of Amphipoda were found: a sub-surface dweller Zenkevitchia sandroruffoi sp. nov. is reported from the Sarma, Trojka and Orlinoe Gnezdo caves at depths from $-30 \mathrm{~m}$ to $-350 \mathrm{~m}$; the second one, a deep dweller Adaugammarus pilosus gen. et sp. nov. is reported from the Sarma Cave at depths of -1270 to -1700 m. Adaugammarus gen. nov. shares similarities with Typhlogammarus Schäferna, 1907 and Zenkevitchia Birstein, 1940. The species Anopogammarus birsteini Derzhavin, 1945 is also re-described herein based on new samples that suggest close affinity of this species with the family Gammaridae. The original taxonomic combination is resurrected for Zenkevitchia revazi Birstein \& Ljovuschkin, 1970, comb. resurr. (from Anopogammarus Derzhavin, 1945). To accommodate morphologically different species in the genus Zenkevitchia, two new groups are proposed. These are the admirabilis-group (Z. admirabilis Birstein, 1940 and Z. yakovi Sidorov, 2015) and the sandroruffoi-group (Z. sandroruffoi sp. nov. and Z. revazi). An updated molecular (mt-coxl) phylogeny, an identification key to the genera and a distribution map for the typhlogammarid amphipod species of Transcaucasia are provided.
\end{abstract}

Keywords. Gammaroidea, mtDNA, phylogeny, Sarma Cave, subterranean species.

Sidorov D.A., Gontcharov A.A. \& Sharina S.N. 2015. A new genus and two new species of cavernicolous amphipods (Crustacea: Typhlogammaridae) from the Western Caucasus. European Journal of Taxonomy 168: 1-32. http://dx.doi.org/10.5852/ejt.2015.168 


\section{Introduction}

The Arabika karst massif is one of the largest and highest in the limestone band of the Western Caucasus. It is bounded by the canyons of the rivers Kutu-Sara, Gega and Bzyb on the North and East, by the Black Sea coast on the Southwest and by the valleys of the Khashupse and Tsandrypsh rivers in the West. The following separation and nomenclature for the speleological areas of the Arabika massif is adopted: the Ortobalagan trough, Gel'geluk trough, Treugol'nik caving district (Zont-Utug-Khyrka), Minskaja Valley trough and the Dzou tract.

Since Birstein and co-authors (Birstein 1940; Birstein \& Lopaschov 1940) presented their first studies on the biodiversity of subterranean animals in Transcaucasia, both significant speleological discoveries were made and taxonomic views changed considerably. Dozens of new caves have been explored (Dublyansky et al. 1987) and several new taxa have been discovered (Birstein \& Ljovuschkin 1967). The contemporary period is marked by several publications on the cavernicolous fauna of the region (Marin \& Sokolova 2014; Vinarski et al. 2014; Sidorov et al. 2015), including biospeleological studies on caves located in the Arabika massif (Jordana et al. 2012; Sendra \& Reboleira 2012; Sidorov et al. 2014). However, the invertebrate troglofauna of the Western Caucasus and surrounding areas is still poorly known (Barjadze et al. 2015).

The family Typhlogammaridae was proposed by Bousfield (1978) and consists of five genera: Typhlogammarus Schäferna, 1907; Metohia Absolon, 1927; Zenkevitchia Birstein, 1940; Anopogammarus Derzhavin, 1945 and Accubogammarus G. Karaman, 1974 (Schäferna 1907; Absolon 1927;

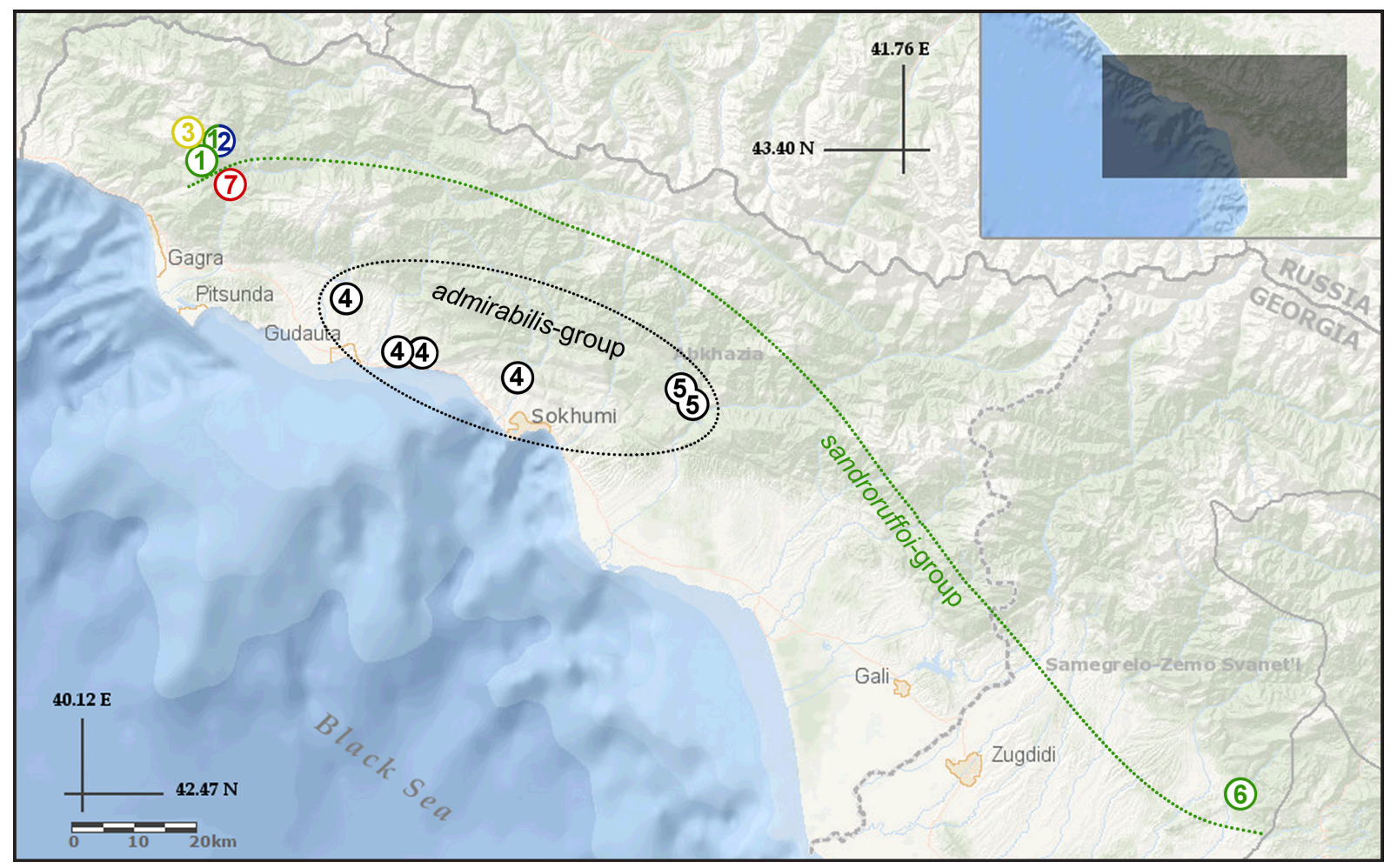

Fig. 1. Distribution map of Typhlogammaridae species and Anopogammarus in the Transcaucasia. 1. Zenkevitchia sandroruffoi sp. nov. 2. Adaugammarus pilosus gen. et sp. nov. 3. Zenkevitchia sp. sensu Jaume in Sendra \& Reboleira (2012). 4. Zenkevitchia admirabilis (complex of species). 5. Zenkevitchia yakovi Sidorov, 2015. 6. Zenkevitchia revazi Birstein \& Ljovuschkin, 1970, comb. resurr. 7. Anopogammarus birsteini Derzhavin, 1945. 
SIDOROV D.A. et al., New genus and species of Typhlogammaridae

Birstein 1940; Derzhavin 1945; Karaman 1974). The typhlogammarids mostly inhabit subterranean waters in caves and are sometimes observed in the karstic springs of the Balkan-Transcaucasian region. An interesting feature of this group of invertebrates is their ability to move across the stone surface within a thin film of water, the so-called "cave hygropetric habitat" (Sket 2004).

In this paper, we present results of a biospeleological survey from the most studied caving area, Treugol'nik, with about 30 known caves including one of the world's deepest caves, the Sarma Cave. The Sarma, Trojka and Orlinoe Gnezdo caves were studied and among other things (Sidorov et al. 2014), amphipods of the Typhlogammaridae family were collected there. The DNA barcode region of the mitochondrial cytochrome c oxidase subunit 1 (COI) gene sequence was used to verify the distinction of described species, along with comparative morphological analyses.

\section{Material and methods}

\section{Specimen collection}

The samples of blind, unpigmented aquatic amphipods were collected in three limestone caves; the meters refer to the explored cave depth: Sarma (-1830 m), Trojka (-257 m), and Orlinoe Gnezdo (-75 m) in the Arabika massif of Abkhazia (Fig. 1, Table 1). Additionally, samples containing specimens of Anopogammarus birsteini Derzhavin, 1945 were collected at the type locality near Goluboe Lake in the Gagra District of Abkhazia. Specimens were preserved in 96\% ethanol at each field site. The geographical map showing the sampling sites and distribution pattern of the Typhlogammaridae species in the Western Caucasus was constructed with GMT 4.5.6.-1. GIS software (Fig. 1).

\section{Morphology and taxonomic terms}

The body length of the amphipods was recorded by holding the specimen straight and measuring the distance along the dorsal side of the body from the base of the first antenna to the base of the telson, using a micrometer eye piece in a Lomo MBS-9 dissecting microscope. Appendages were drawn with a Carl Zeiss NU-2 compound microscope equipped with a drawing device as described in Gorodkov (1961). Heavily calcified specimens of crustaceans were placed in $4 \%$ lactic acid and then washed and boiled in clean water to remove air bubbles within the segments. Permanent preparations were made using a methylene blue staining solution, and polyvinyl lactophenol (PVL) was used as the mounting medium. The descriptive terminology follows the classification system in the original conventional sense and does not agree with the homology concepts proposed by Watling (1989). To make the nomenclature more stable, we use the term "spine" for robust setae and the term "seta" for slender, usually flexible structures. The term "palmar angle" of the gnathopod propodi refers to the angle formed at the end of the palm and beginning of the posterior margin or at the point where the tip of the dactylus closes on the propodus (Birstein 1941). The fore-gut lateralia comprise a potentially useful morphological character in the phylogenetic analysis (Coleman 1991). The nomenclature for setal patterns on article 3 of the mandibular palp follows the practice of Karaman (1970) and Stock (1974). The descriptions are based on the type series and all material examined is deposited in the Zoological Museum of the Far East Federal University, Vladivostok (FEFU; the holotypes are kept there) or in the research collection of D.A. Sidorov at the Institute of Biology and Soil Science, Vladivostok (IBSS).

\section{DNA extraction, amplification, sequencing and analysis}

Total DNA was extracted from the muscle tissue with a DNeasy Blood \& Tissue kit (QIAGEN GmbH, Hilden, Germany) according to the manufacturer's protocol. The COI gene fragment was amplified using the universal primers HCO2198 and LCO1490 (Folmer et al. 1994). The annealing temperature was set at $40^{\circ} \mathrm{C}$ for $20 \mathrm{~s}$. The PCR products were sequenced directly using the same primers and a BigDye terminator v. 3.1 sequencing kit (Applied Biosystems, USA). Sequences were analyzed on an ABI 3130 genetic analyzer (Applied Biosystems, USA) and assembled with the Staden Package v. 1.4 
Table 1. List of the specimens, sampling sites and accession numbers of the sequences included in this study. References are given for sequences obtained from GenBank.

\begin{tabular}{|c|c|c|c|}
\hline Specimen & Locality & $\begin{array}{c}\text { GenBank } \\
\text { acc. no. } \\
\text { COI }\end{array}$ & $\begin{array}{l}\text { Reference/ } \\
\text { or year of } \\
\text { sampling }\end{array}$ \\
\hline $\begin{array}{l}\text { Adaugammarus pilosus } \\
\text { SC1270m1 }\end{array}$ & Georgia, Abkhazia: Sarma Cave, $-1270 \mathrm{~m}$ & KT427516 & This study (2011) \\
\hline $\begin{array}{l}\text { Adaugammarus pilosus } \\
\text { SC1270m2 }\end{array}$ & Georgia, Abkhazia: Sarma Cave, $-1270 \mathrm{~m}$ & KT427517 & This study (2011) \\
\hline $\begin{array}{l}\text { Adaugammarus pilosus } \\
\mathrm{SC} 1270 \mathrm{~m} 3\end{array}$ & Georgia, Abkhazia: Sarma Cave, $-1270 \mathrm{~m}$ & KT427518 & This study (2011) \\
\hline Adaugammarus pilosus $\mathrm{SC} 1700 \mathrm{~m}$ & Georgia, Abkhazia: Sarma Cave, $-1700 \mathrm{~m}$ & KT427519 & This study (2011) \\
\hline $\begin{array}{l}\text { Zenkevitchia sandroruffoi } \\
\mathrm{SC} 230 \mathrm{~m}\end{array}$ & Georgia, Abkhazia: Sarma Cave, $-230 \mathrm{~m}$ & KT427520 & This study (2012) \\
\hline $\begin{array}{l}\text { Zenkevitchia sandroruffoi } \\
\text { SC } 350 \mathrm{~m}\end{array}$ & Georgia, Abkhazia: Sarma Cave, $-350 \mathrm{~m}$ & KT427521 & This study (2012) \\
\hline Zenkevitchia sandroruffoi $\mathrm{TC}$ & Georgia, Abkhazia: Trojka Cave, $-30 \mathrm{~m}$ & KT427522 & This study (2012) \\
\hline Zenkevitchia sandroruffoi OG1 & Georgia, Abkhazia: Orlinoe Gnezdo Cave, $-75 \mathrm{~m}$ & KT427523 & This study (2011) \\
\hline Zenkevitchia sandroruffoi OG2 & Georgia, Abkhazia: Orlinoe Gnezdo Cave, -75 m & KT427524 & This study (2011) \\
\hline Zenkevitchia sandroruffoi OG3 & Georgia, Abkhazia: Orlinoe Gnezdo Cave, -75 m & KT427525 & This study (2011) \\
\hline \multicolumn{4}{|c|}{ From GenBank } \\
\hline $\begin{array}{l}\text { Accubogammarus sp. } \\
\text { SLOCHN114 }\end{array}$ & Montenegro: Grahovo, Vojvode Dakovića cave & KF478592 & Hou et al. 2014 \\
\hline $\begin{array}{l}\text { Anopogammarus revazi } \\
\text { SLOCHN245 }\end{array}$ & Georgia: Martvili, Motena cave & KF478522 & Hou et al. 2014 \\
\hline Metohia carinata SLOCHN019 & Montenegro: Rijeka Crnojevića, Obodska cave & KF478584 & Hou et al. 2014 \\
\hline Metohia carinata SLOCHN025 & $\begin{array}{l}\text { Bosnia-Herzegovina: Čičevo, Velja gora, Šumet } \\
\text { cave }\end{array}$ & KF478585 & Hou et al. 2014 \\
\hline $\begin{array}{l}\text { Typhlogammarus mrazeki } \\
\text { SLOCHN020 }\end{array}$ & $\begin{array}{l}\text { Bosnia-Herzegovina: Popovo polje, Zavala, } \\
\text { Vjetrenica cave }\end{array}$ & KF478586 & Hou et al. 2014 \\
\hline $\begin{array}{l}\text { Typhlogammarus mrazeki } \\
\text { SLOCHN113 }\end{array}$ & Montenegro: Cetinje, Lipska cave & KF478590 & Hou et al. 2014 \\
\hline $\begin{array}{l}\text { Typhlogammarus sp. } \\
\text { SLOCHN252 }\end{array}$ & Croatia: Zrmanja, Krupa cave & KF478591 & Hou et al. 2014 \\
\hline $\begin{array}{l}\text { Zenkevitchia admirabilis } \\
\text { SLOCHN199 }\end{array}$ & $\begin{array}{l}\text { Georgia, Abkhazia: Suhumi, Verhnie Pešeri, } \\
\text { Verhne-esherskaja (=Sobachya) cave, approx. } \\
43^{\circ} 0658 \mathrm{~N}, 40^{\circ} 9922 \mathrm{E}\end{array}$ & KF478600 & Hou et al. 2014 \\
\hline $\begin{array}{l}\text { Zenkevitchia admirabilis } \\
\text { SLOCHN200 }\end{array}$ & $\begin{array}{l}\text { Georgia, Abkhazia: Gudauta, Lihni, Tarkili } \\
\text { (=Tarkiladze) cave, } 43.19441 \text { N, } 40.65165 \mathrm{E}\end{array}$ & KF478599 & Hou et al. 2014 \\
\hline Zenkevitchia yakovi $\mathrm{T}$ & $\begin{array}{l}\text { Georgia, Abkhazia: "Istočnik Tcebel'da" cave, } \\
43^{\circ} 0262 \mathrm{~N} 41^{\circ} 2830 \mathrm{E}\end{array}$ & KP844572 & Sidorov et al. 2015 \\
\hline Zenkevitchia yakovi $\mathrm{S} 1$ & $\begin{array}{l}\text { Georgia, Abkhazia: Sredne-Shakuranskaya cave, } \\
43^{\circ} 0297 \text { N } 41^{\circ} 3331 \mathrm{E}\end{array}$ & KP844573 & Sidorov et al. 2015 \\
\hline Zenkevitchia yakovi $\mathrm{S} 2$ & $\begin{array}{l}\text { Georgia, Abkhazia: Sredne-Shakuranskaya cave, } \\
43^{\circ} 0297 \text { N } 41^{\circ} 3331 \mathrm{E}\end{array}$ & KP844574 & Sidorov et al. 2015 \\
\hline
\end{tabular}


(Bonfield et al. 1995). The Akaike information criterion (AIC2) in ModelGenerator 0.85 (Keane et al. 2006) was used to select the model of sequence evolution best fitting our data set $(\mathrm{HKY}+\mathrm{G}+\mathrm{I})$. The data set was analyzed using the maximum-likelihood (ML) algorithm in Mega 6.0 (Tamura et al. 2013), and pairwise sequence divergence was estimated using the same environment. A standard BioNJ initial tree was obtained automatically by applying the Nearest-Neighbor-Interchange (NNI) for tree inference. To assess support for clades 1,000 bootstrap replicates (Felsenstein 1985) were performed.

$$
0
$$

$0 \quad$ Entrance 2150 orthonetric height

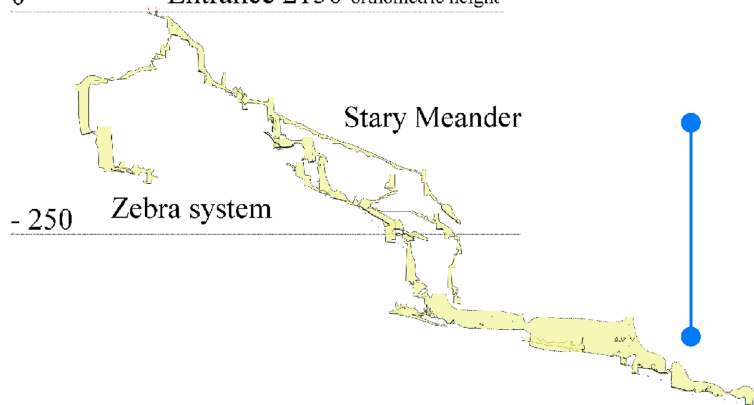

$-500$

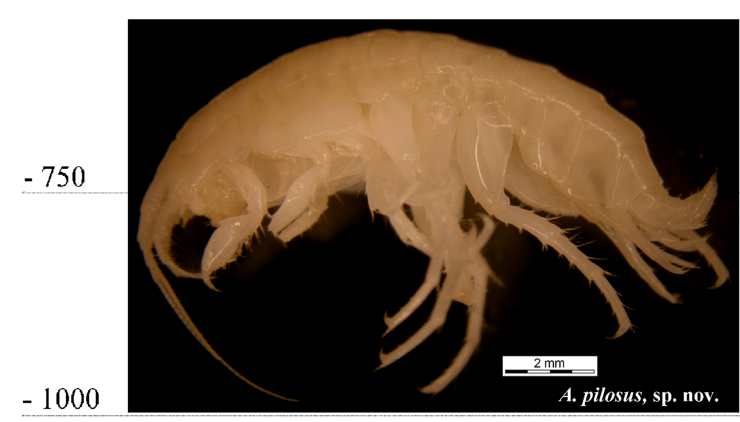

P250 Champion

\section{Zenkevitchia sandroruffoi}
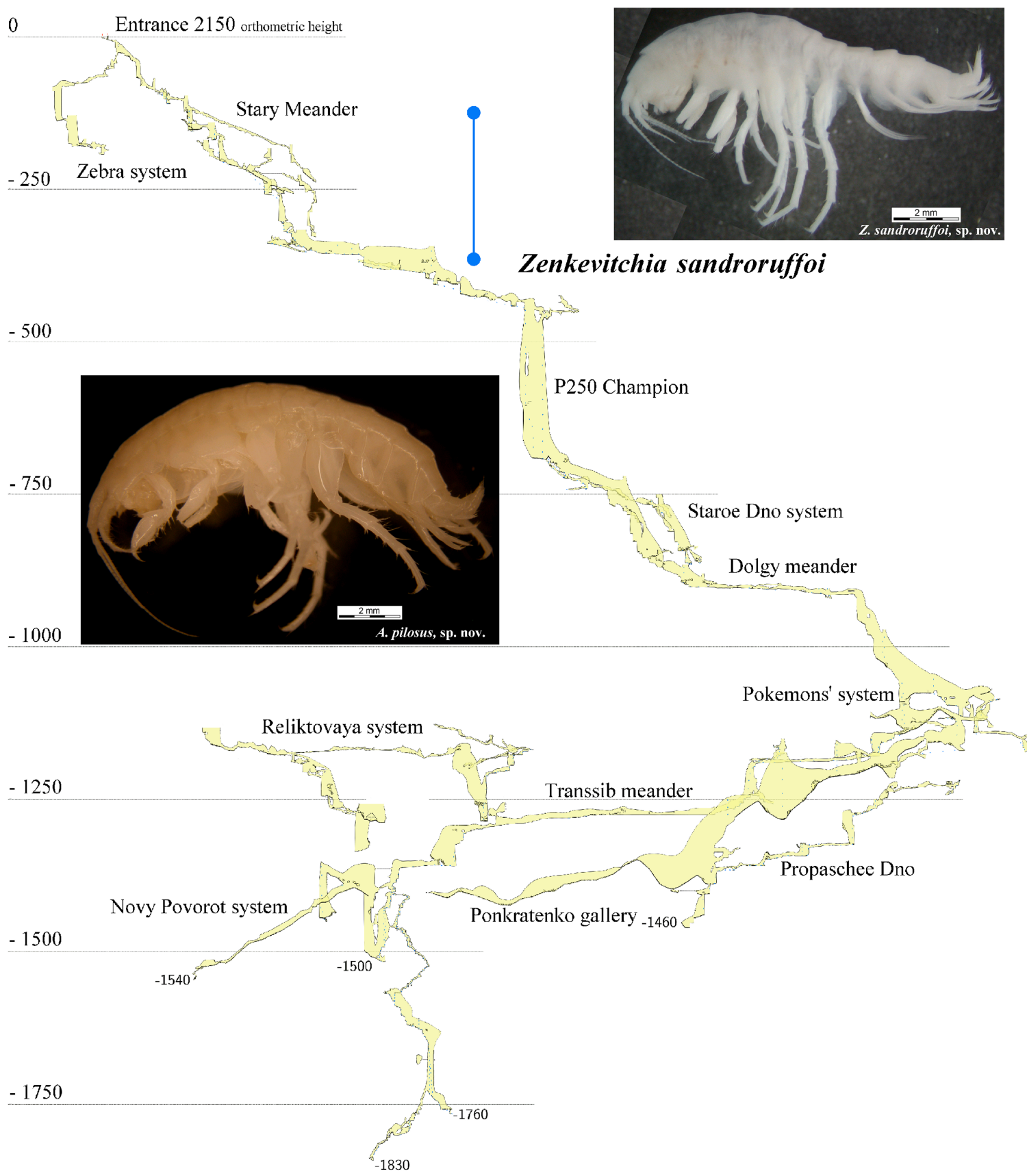

Fig. 2. Vertical distribution of amphipod species in the Sarma Cave. Map adapted from Sidorov et al. (2014), compiled by V.V. Sukhachev. 


\section{Results}

Order Amphipoda Latreille, 1818

Family Gammaridae Leach, 1814

Genus Anopogammarus Derzhavin, 1945

Anopogammarus birsteini Derzhavin, 1945

Figs 4A-E, 5-6

Anopogammarus birsteini Derzhavin, 1945: 34, pl. 2.

Anopogammarus birsteini - Birstein \& Ljovuschkin 1967: 1512; 1970: 1478, figs 4-6. — Stock 1973: 339. — Bousfield 1977: 291. — Karaman \& Barnard 1979: 142. — Barnard \& Karaman 1980: 8. — Barnard \& Barnard 1983: 502. — Ruffo 1995: 450. — Karaman \& Ruffo 1995: 159, 160.

\section{Material examined}

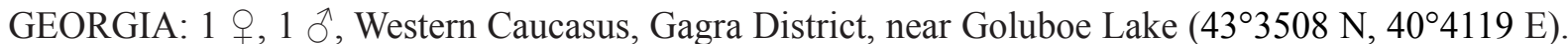
Specimens, completely dissected and mounted on a single slide per number: + (oostegites initial, nonsetose) $9.0 \mathrm{~mm}$, के $8.5 \mathrm{~mm}, 15$ Jun. 2015, $133 \mathrm{~m}$ a.s.1., springs, coll. D.M. Palatov (X44039/Cr-164546-FEFU).

\section{Additional material examined}

GEORGIA: 5 오 $(6.0 \mathrm{~mm}, 3 \times 7.0 \mathrm{~mm}, 7.5 \mathrm{~mm}$; oostegites initial, non-setose), $5 \hat{\jmath} \hat{\jmath}(3 \times 6.0 \mathrm{~mm}, 7.5 \mathrm{~mm}$, $9.0 \mathrm{~mm}), 3$ juv., specimens measured, partially dissected and stored in different vials (1-12/1sd-IBSS), same data as above.

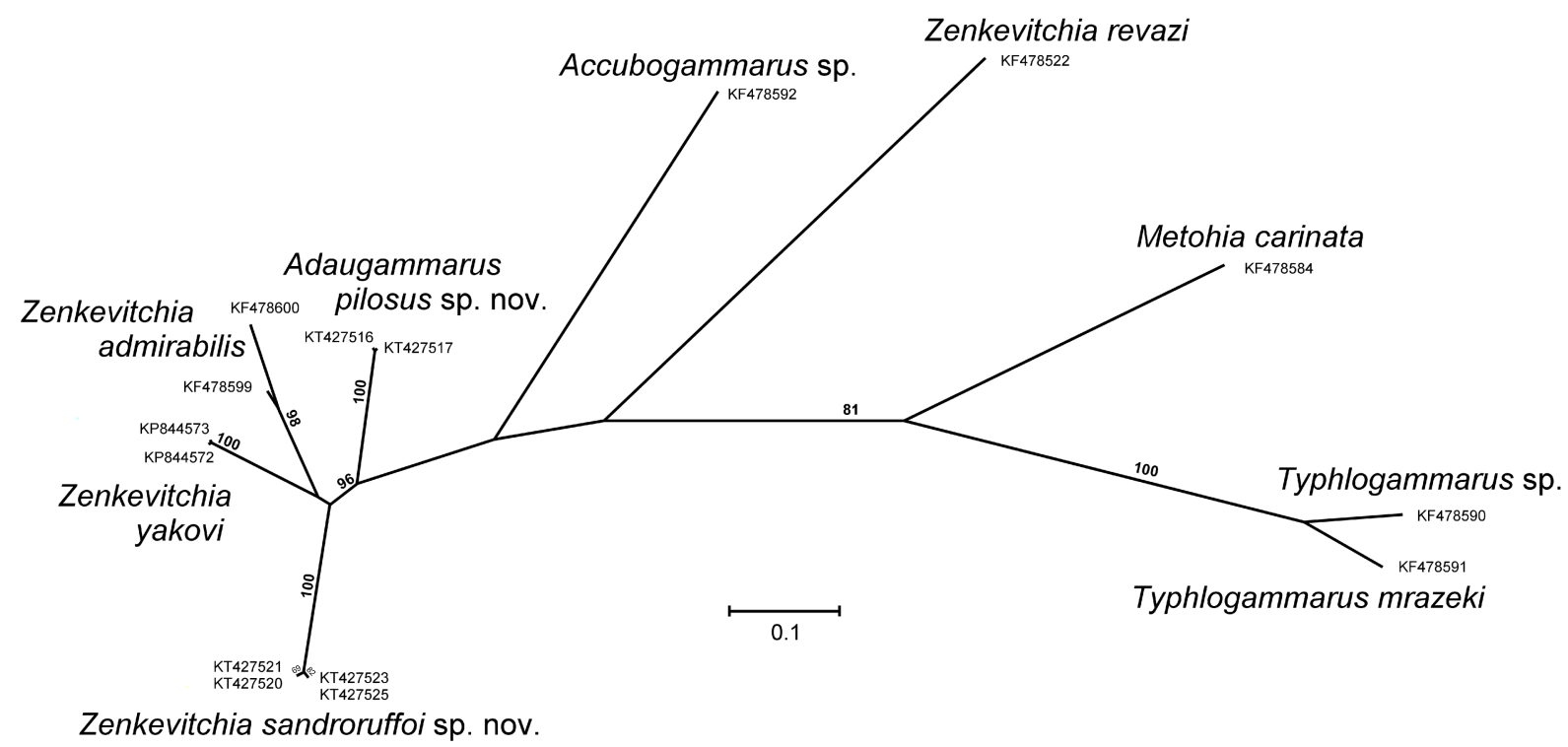

Fig. 3. Unrooted ML-tree with bootstrap support values based on the mt-coxl sequences (values less than $50 \%$ not shown). Specimen labels refer to information given in Table S1. Scale bar indicates the number of substitutions per site. 

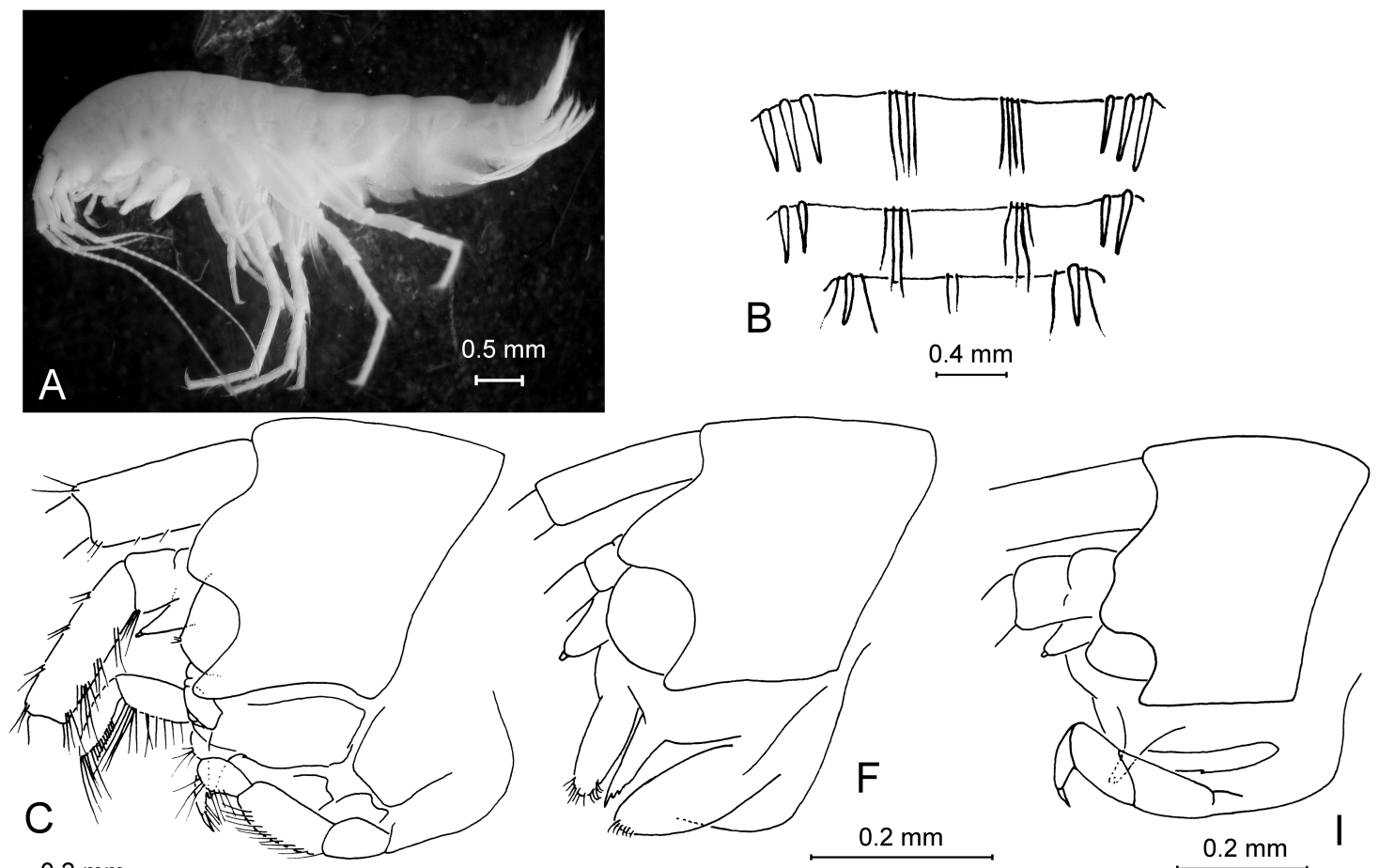

$0.2 \mathrm{~mm}$
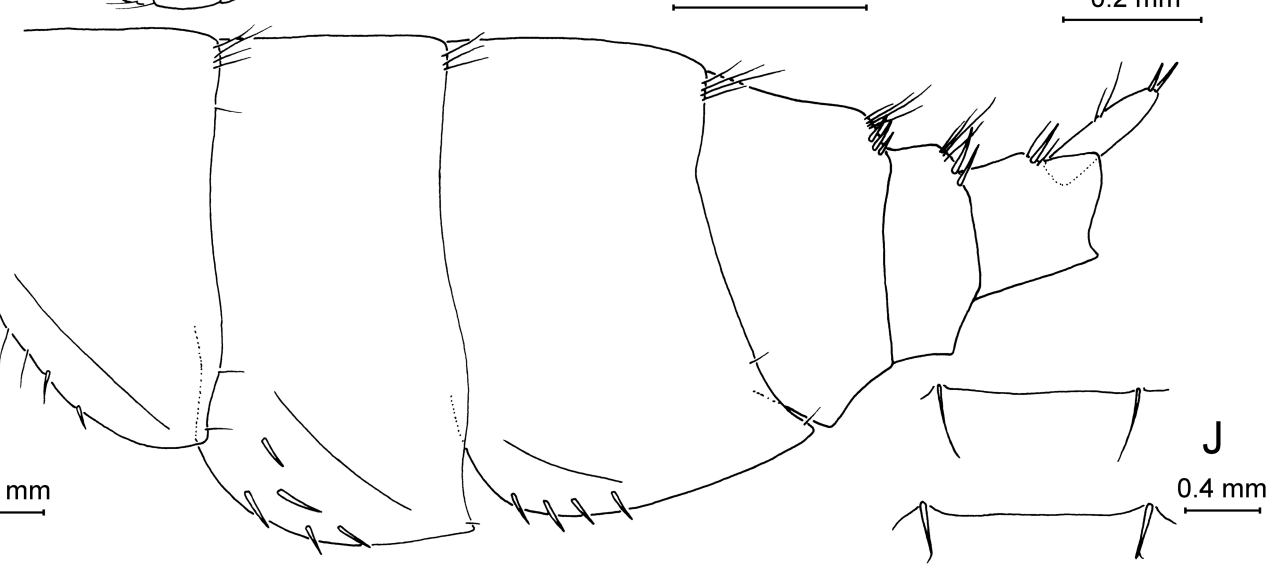

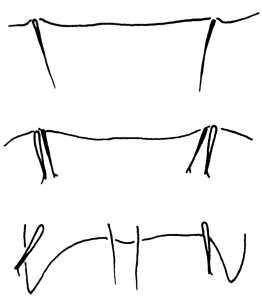

G

$0.4 \mathrm{~mm}$

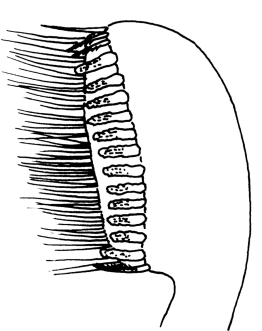

$\mathrm{H}$

$0.05 \mathrm{~mm}$

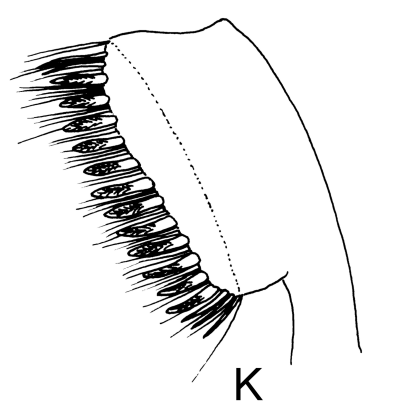

$0.05 \mathrm{~mm}$

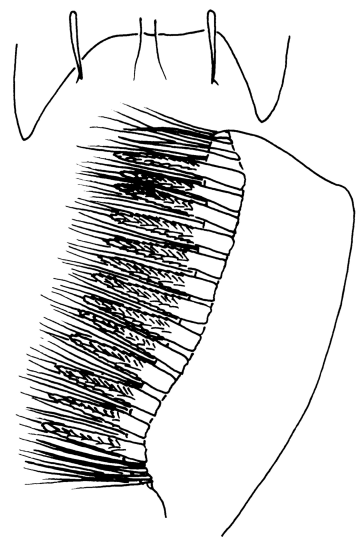

Fig. 4. - A-D. Anopogammarus birsteini Derzhavin, 1945. +, $9.0 \mathrm{~mm}, \mathrm{X} 44039 / \mathrm{Cr}-1645-\mathrm{FEFU}$ : A. Habitus from left side. B. Urosome. C. Head. D. Metasomal and urosomal segments with telson. E-G. Zenkevitchia sandroruffoi sp. nov. Paratype, 9 , $6.3 \mathrm{~mm}$, X44045/Cr-1651-FEFU. E. Lateralia. F. Head. G. Urosome. - H-K. Adaugammarus pilosus sp. nov. Holotype, $\$$, 13.5 mm, X44046/Cr1652-FEFU. H. Lateralia. I. Head. J. Urosome. K. Lateralia. 


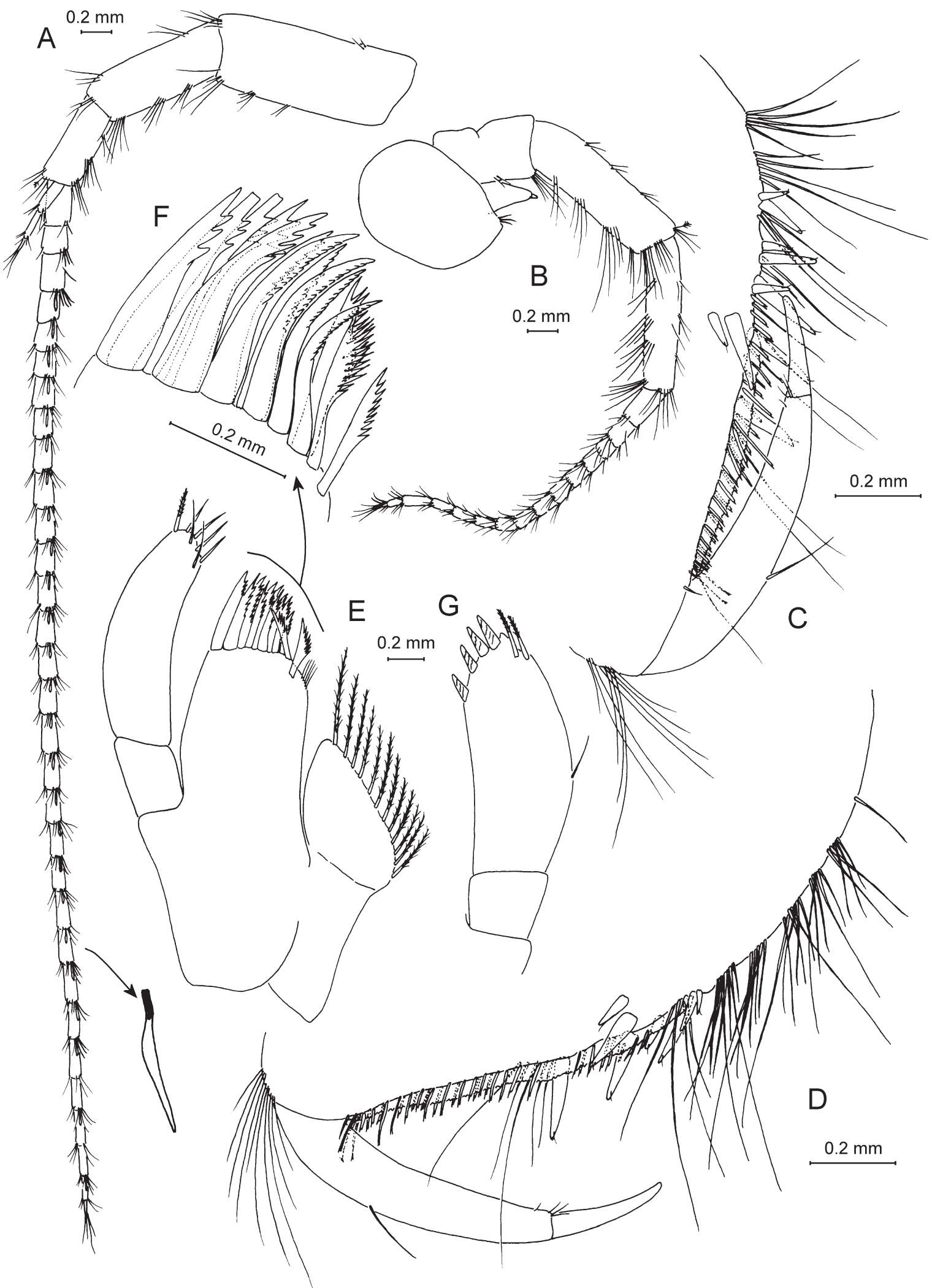

Fig. 5. Anopogammarus birsteini Derzhavin, 1945. ${ }^{\circ}, 9.0 \mathrm{~mm}, \mathrm{X} 44039 / \mathrm{Cr}-1645-\mathrm{FEFU}$. A. Antenna 1. B. Antenna 2. C-D. Palmar margins of gnathopods 1 and 2 propodi. E. Maxilla 1. F. Outer plate of maxilla 1. G. Palp of right maxilla 1. 


\section{Remark}

Although A. birsteini was described by Derzhavin (1945) based on an $8.0 \mathrm{~mm}$ female and was subsequently redescribed in detail (Birstein \& Ljovuschkin 1970) based on both sexes, we further introduce an amended diagnostic description to emphasize some important characters.

\section{Diagnostic description}

SizE. Female body length $9.0 \mathrm{~mm}$ and male, body length $8.5 \mathrm{~mm}$ (X44039/Cr-1645-46-FEFU). Robust, large-sized species of gammarid-like habitus (sexual dimorphism weakly pronounced, i.e., females larger than males). Coxal gills 2-7 stalked, triangular or sacciforme, largest on gnathopod 2, successively smaller on pereopods 3 to 7 , gill 7 the smallest. Body length $6.0-17.0 \mathrm{~mm}$ () $), 6.0-14.0 \mathrm{~mm}($ む).

General Body morphology (Figs 4A-D, 6G). Body smooth, lacking dorsal cuticular elements. Head as long as first pereon segment; rostrum absent; inferior antennal sinus shallow, sub-rounded. Eyes absent. Pleosomites and urosomites on dorsal surface with lateral groups of spines and setae; medial elements absent. Dorsal surface of urosomites 1-3 armed with robust spines in the following manner: 1 (3-0-0-3), 2 (2-0-0-2), 3 (1-0-1). Epimeral plate 1: postero-ventral corner prominent; posterior and ventral margins convex; 2 stiff setae along ventral margin, 2 setae along posterior margin. Epimeral plate 2: postero-ventral corner acuminate; posterior and ventral margins convex; 5 stiff setae in two rows along ventral margin, 1 seta along posterior margin at corner. Epimeral plate 3: postero-ventral corner

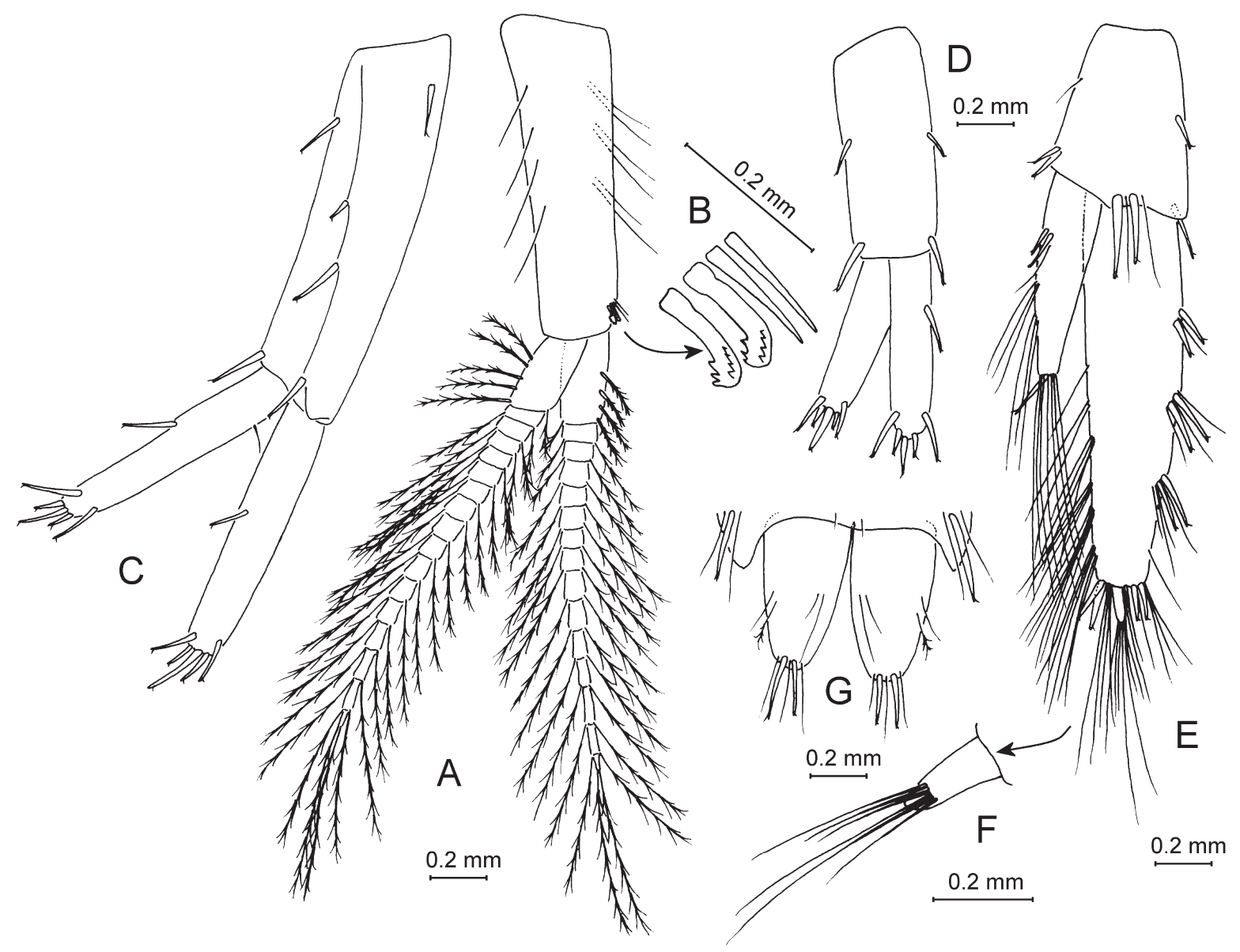

Fig. 6. Anopogammarus birsteini Derzhavin, 1945. ㅇ, 9.0 mm, X44039/Cr-1645-FEFU. A. Pleopod 2. B. Coupling setae of pleopod 2. C. Uropod 1. D. Uropod 2. E-F. Uropod 3. G. Telson. 
acuminate; posterior margin concave; ventral margin convex; 4 stiff seta along ventral margin, 2 setae along posterior margin. Telson as long as broad; cleft entirely; 2 or 3 apical spines per lobe present, these are $0.2 \times$ telson length, each accompanied by setae. Antennae (Figs 4A, 5A-B). Antenna $10.65 \times$ of body length; main flagellum with up to 30-32 articles; almost all flagellar articles bearing small aesthetascs accompanied by $2-8$ short setae; peduncular articles in ratio 1:0.7:0.4; proximal article of peduncle with 3 sets of short setae along ventral margin; accessory flagellum 3- or 4-articulated. Length ratio of antenna 1 to antenna 2 is 1:0.5; flagellum of antenna 2 with 11-15 articles, each article densely setose; length ratio of peduncle articles 4 and 5 is 1:0.9; flagellum as long as peduncle (articles 4+5); peduncular articles 4 and 5 with sets of long stiff setae along ventral margin; gland cone short.

Mouth PARTs (typical gammarid, Figs 5E-G). Maxilla 1 palp longer than outer plate, distal article with 5 apical and 2 sub-apical setae (both palps asymmetric, right palp broader, with 4-5 strong spines and 2 plumose setae on apex and 1-2 setae on outer margin); outer plate with 12-14 spines (5 poorly toothed and 9 multi-toothed); inner plate trapezoidal, with 12 plumose setae. Foregut lateralia with 13 strong pectinate spines and densely setose row of stiff setae.

Gnathopods 1-2 (Fig. 5C-D). Gnathopod 1: propodus almond-shaped, palm convex, with cutting margin acanthaceous and $2 \times$ longer than posterior margin; along posterior margin two sets of simple setae; antero-distal group of anterior margin with 10 setae; palmar margin with short, notched setae along outer and inner faces, palmar angle undefined, a group of 10 distally-notched strong spines on both faces (with 2 strong mid-palmar spines in the place where tip of nail close); nail long, $0.25 \times$ total length of dactylus, 1 seta along anterior margin, with 4 setules at hinge. Gnathopod 2: propodus small (compared to the body) and slightly larger than propodus of gnathopod 1; propodus almond-shaped, palm convex, with cutting margin acanthaceous and as long as posterior margin; posterior margin with 6 sets of stiff setae; antero-distal group of anterior margin with 10 setae; palmar margin with short, notched setae along outer and inner faces, palmar angle undefined, a group of 8 distally-notched strong spines on both faces (with 2 strong mid-palmar spines in the place where tip of nail close); dactylus similar to that of gnathopod 1.

Pleopods (Fig. 6A-B). Pleopods 1-3 sub-equal, each with 2 coupling setae (retinacula) accompanied by 1-3 stiff setae; peduncular articles fringed with long, thin setae; proximal article of inner rami fringed with 4 setae. Pleopods 1-3 rami with 15-19 articles each.

Uropods (Figs 4A, 6C-F). Uropod 1 protopodite with 1 basofacial spine, 3 dorso-lateral spines and 2 dorso-medial spines; exopodite as long as endopodite; rami straight, with single spines along outer margins; both with 5 spines apically and sub-apically (two of them strong). Uropod 2 endopodite slightly shorter than exopodite. Uropod 3 protopodite with 3 groups of spines on apex; endopodite as long as protopodite, with 1 spine and 7 long setae apically; exopodite 2 -articulated, about $2.2 \times$ longer than protopodite, with 3 groups of lateral spines, 6 groups of long simple setae along inner margin; proximal article with 4 spines and about 10 long setae on apex, terminal article short, $0.09 \times$ as long as proximal article, with 6 long simple setae sub-apically.

\section{Discussion of affinities}

Describing the monotypic genus Anopogammarus Derzhavin (1945) noted a lack of eyes in A. birsteini as the only difference from the genus Gammarus and considered this feature characteristic. Later, Birstein \& Ljovuschkin (1970) re-described Anopogammarus birsteini in detail and considered this species, along with Metohia carinata Absolon, 1927, as derived from Gammarus, implying a subgeneric status for the genera Anopogammarus and Metohia. However, according to their view, Zenkevitchia revazi occupies an intermediate position between the specialized Zenkevitchia admirabilis and Gammarus (Stock 1973). Subsequently, Karaman \& Barnard (1979) transferred Z. revazi to Anopogammarus, based on the non-moplike structure of maxilla 1 and reduced palps in the former species. Later, the same authors 
SIDOROV D.A. et al., New genus and species of Typhlogammaridae

(Barnard \& Karaman 1980) again confirmed that Anopogammarus, along with the rest of the taxa placed in the Family group 2 (Typhlogammarus group, hypogean large gammarids) sensu Bousfield (1977), has no strong distinction from the Gammarus-Echinogammarus group (see Barnard \& Karaman 1980: 7-9). Ruffo (1995) and Karaman \& Ruffo (1995), describing two genera of cavernicolous amphipods (Albanogammarus and Sinogammarus from Albania and Southwest China, respectively), discussed the position of the new taxa in depth and hypothesized an obvious affinity with Anopogammarus.

The revision of the group cannot be considered as completed, because the genus Anopogammarus is heterogeneous and needs to be split. We propose transferring Anopogammarus revazi to the genus Zenkevitchia (Zenkevitchia revazi Birstein \& Ljovuschkin, 1970, comb. resurr.) and to the newly proposed group (sandroruffoi-group). The monotypic genus Anopogammarus based on Anopogammarus birsteini Derzhavin, 1945, however, should be considered a component of the family Gammaridae. As the above-mentioned authors, we believe that the monotypic genus Anopogammarus has an affinity to Albanogammarus and Sinogammarus. This assumption is based on the following shared features: the structure of the anterior margin of the cephalon (lateral interantennal lobes slightly subquadrate); powerful dorsal armament of urosomal segments; antenna 1 with small aesthetascs in males (? lacking in Albanogammarus); calceoli on antenna 2 absent; article 1 of antenna 2 being rather large, bearing short setae, and antennal gland cone short; structure of maxilla 1 (outer plate with multi-toothed non-falcate spines and palps clearly asymmetric); uropod 3 long and with 2-articulated outer ramus.

Family Typhlogammaridae Bousfield, 1978

Genus Zenkevitchia Birstein, 1940

Zenkevitchia Birstein, 1940: 51, fig. 4.

Zenkevitchia - Birstein 1941: 260, figs 1-3; 1950: 356. — Derzhavin 1945: 34. - Birstein \& Ljovuschkin 1970: 1472, fig. 1. — Bousfield 1977: 291. — Barnard \& Barnard 1983: 507.

sandroruffoi-group

\section{Remarks}

Although, as described below, Zenkevitchia sandroruffoi sp. nov. differs from other species of Zenkevitchia (Z. admirabilis, Z. yakovi) in the non-filtrative maxilla 1, we decided that it, along with $Z$. revazi, differs sufficiently to warrant recognition as a new species group within the genus Zenkevitchia, which we here designate as the sandroruffoi-group. The sandroruffoi-group ( $Z$. sandroruffoi sp. nov. and $Z$. revazi Birstein \& Ljovuschkin, 1970) is phenotypically more distant from the type species of the genus Zenkevitchia, bearing only up to 22 multi-toothed spines (non-falcate in shape). In some sense, the group occupies an intermediate position between Zenkevitchia (admirabilis-group) and other species of the Typhlogammaridae (cf. Accubogammarus), although, in our opinion, it is closer to the former. The indicators for affinity to Zenkevitchia are: interantennal cephalic lobes sub-acute, urosomal segments weakly armed, shortened antenna 1, antennal gland cone of antenna 2 long, reduced and subsymmetrical palps of maxilla 1, structure and armament of gnathopods (both appendages with welldefined palmar angle).

Despite these points of similarity, Z. revazi needs re-description because some features, such as sexual dimorphism, were not described properly, although important characters that clearly differentiate both species (characteristics of $Z$. sandroruffoi sp. nov. in parentheses in the following list) are evident. These are: outer plate of maxilla 1 with 11 spines (22 spines), palps of maxilla 1 asymmetric, reduced (sub-symmetric, cf. Typhlogammarus m. mrazeki Schäferna, 1907 and T. m. heteropalpus Karaman, 1972; Karaman 1972, 1988) body of mandibles compacted (elongated), bases of pereopods 5-7 without 
lobes (with extraordinary roundish postero-proximal lobes), uropod 3 well-developed, setose with plumose setae (reduced, weakly setose). Zenkevitchia revazi reveals a number of features in common with Accubogammarus and the minor differences between these taxa (Karaman 1973, 1974, 1988) are mainly related to the structure of uropod 3 .

\section{Zenkevitchia sandroruffoi sp. nov. urn:1sid:zoobank.org:act:707E6585-8A2E-47BA-802A-8349FAA1AAA2}

Figs 2, 4F-H, 7-11

\section{Diagnosis (both sexes)}

Robust, middle-sized species of gammarid-like habitus (sexual dimorphism weakly pronounced, i.e., males usually larger than females, antenna 2 and both gnathopods sexually dimorphic). Antenna 1 short, reaching $40 \%$ length of body; antenna 2 short, reaching about $60 \%$ length of antenna 1 , gland cone long, reaching half of peduncle of segment 4 . Maxilla 1 inner plate triangular, with 16 plumose setae, outer plate of non-filtration type (?scraper type), with 22 multi-toothed, comb-like spines; palps symmetrical and reduced. Mandibular palp article 3 with 1 A group of 2 setae, 2 B setae, 13 D setae and 4 E setae. Gnathopods 1-2 small, with propodus not larger than corresponding coxa; palmar angles of both gnathopods defined, with a group of notched, strong corner spines; dactyli with 1 seta each along outer margin, nails long. Pereopods 5-7 bases with distinct postero-proximal lobes; inner margin of dactyli of pereopods 3-7 with 1 stiff, notched seta. Urosomites with dorsolateral groups of spines. Pleopods 1-3 with 2 coupling setae (retinacula), each accompanied with 1 seta $(2+1)$. Uropod 1 rami sub-equal, outer ramus scarcely shorter than inner ramus. Uropod 3 short, $0.3 \times$ shorter than uropod 2, endopodite small, $0.6 \times$ shorter than exopodite. Telson with 1 or 2 distal spines per lobe. Coxal gills $2-7$ stalked, triangular or sacciforme, largest on gnathopod 2, successively smaller on pereopods 3 to 7 , gill 7 the smallest. Body length 6.0-8.3 mm (ㅇ), 8.0-12.5 (ぷ).

\section{Etymology}

This species is named in honor of Professor Sandro Ruffo (Museo Civico di Storia Naturale, Verona) for his outstanding contribution in the field of Amphipoda systematics.

\section{Material examined}

Holotype

GEORGIA: sequenced $\partial^{\lambda}, 8.0 \mathrm{~mm}$, Sarma Cave $\left(43^{\circ} 4158 \mathrm{~N}, 40^{\circ} 3633 \mathrm{E}\right.$, approx.), $2346 \mathrm{~m}$ a.s.l., Muzykalnyj meander (sampling depth $-350 \mathrm{~m}$ ), Arabika massif, Gagra District, Western Caucasus, 25 Aug. 2012, coll. E.E. Golubnichaya (X44041/Cr-1647-FEFU).

\section{Paratypes}

GEORGIA: ${ }^{\lambda}, 10.5 \mathrm{~mm}$,, (oostegites developed, weakly setose), $8.3 \mathrm{~mm}$, Sarma Cave (sampling depth -230 m), 28 Aug. 2012, coll. E.E. Golubnichaya (X44042/Cr-1648-51-FEFU); §’, 12.5 mm, Trojka Cave

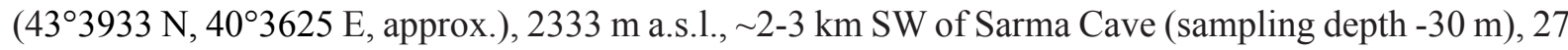
Aug. 2012, coll. E.E. Golubnichaya; + (oostegites developed, weakly setose), $6.3 \mathrm{~mm}$, Orlinoe Gnezdo Cave, $\left(43^{\circ} 3855 \mathrm{~N}, 40^{\circ} 3637 \mathrm{E}\right.$, approx.), $2126 \mathrm{~m}$ a.s.1., $\sim 10 \mathrm{~km} \mathrm{SW}$ of Sarma Cave (sampling depth -75 m), 15 Sep. 2011, coll. L.T. Kharlamova.

\section{Additional material}

GEORGIA: specimens measured, partially dissected and stored in different vials (1-11/2sd-IBSS): 2 우우 with developed oostegites, weakly setose, $7.0 \mathrm{~mm}, 8.0 \mathrm{~mm}$, Sarma Cave, Muzykalnyj meander (sampling depth $-350 \mathrm{~m}$ ), 25 Aug. 2012, coll. E.E. Golubnichaya; 2 우 with developed oostegites, weakly setose, $6.0 \mathrm{~mm}, 7.0 \mathrm{~mm}$, Orlinoe Gnezdo Cave, (sampling depth $-75 \mathrm{~m}$ ), 27 Aug. 2012, coll. E.E. Golubnichaya. 


\section{Differential diagnosis}

Zenkevitchia sandroruffoi sp. nov. can easily be distinguished from the other cavernicolous typhlogammarids by the discriminative humps on its pleonal segments. See 'Remarks' section under sandroruffoi-group as well as the key below.

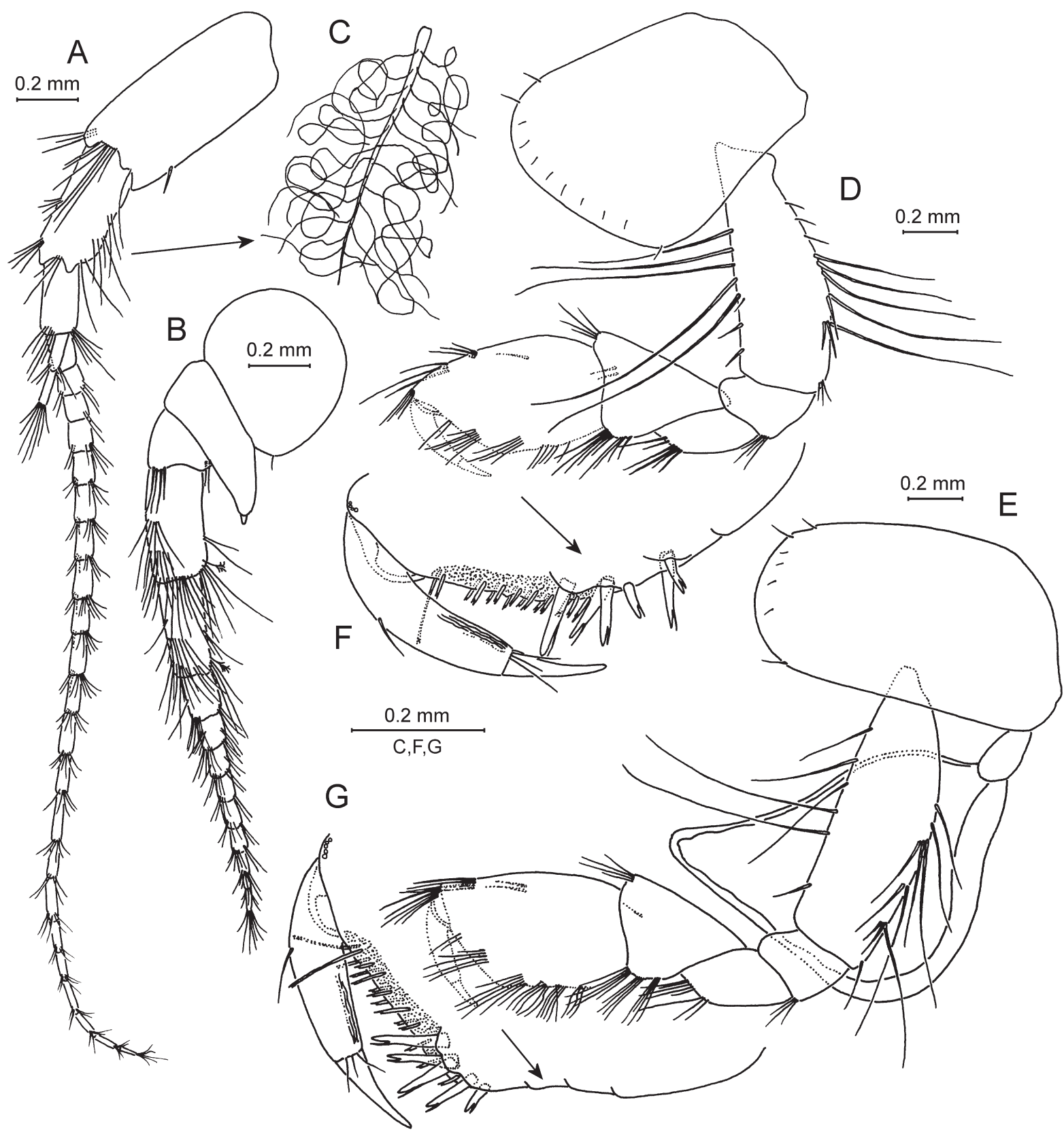

Fig. 7. Zenkevitchia sandroruffoi sp. nov. Holotype, ${ }^{\lambda}, 8.0 \mathrm{~mm}, \mathrm{X} 44041 / \mathrm{Cr}-1647-\mathrm{FEFU}$. A. Antenna 1. B. Antenna 2. C. Barbate seta with attached filamentous algae. D. Gnathopod 1. E. Gnathopod 2. F-G. Palmar margins of gnathopods 1 and 2 propodi. 


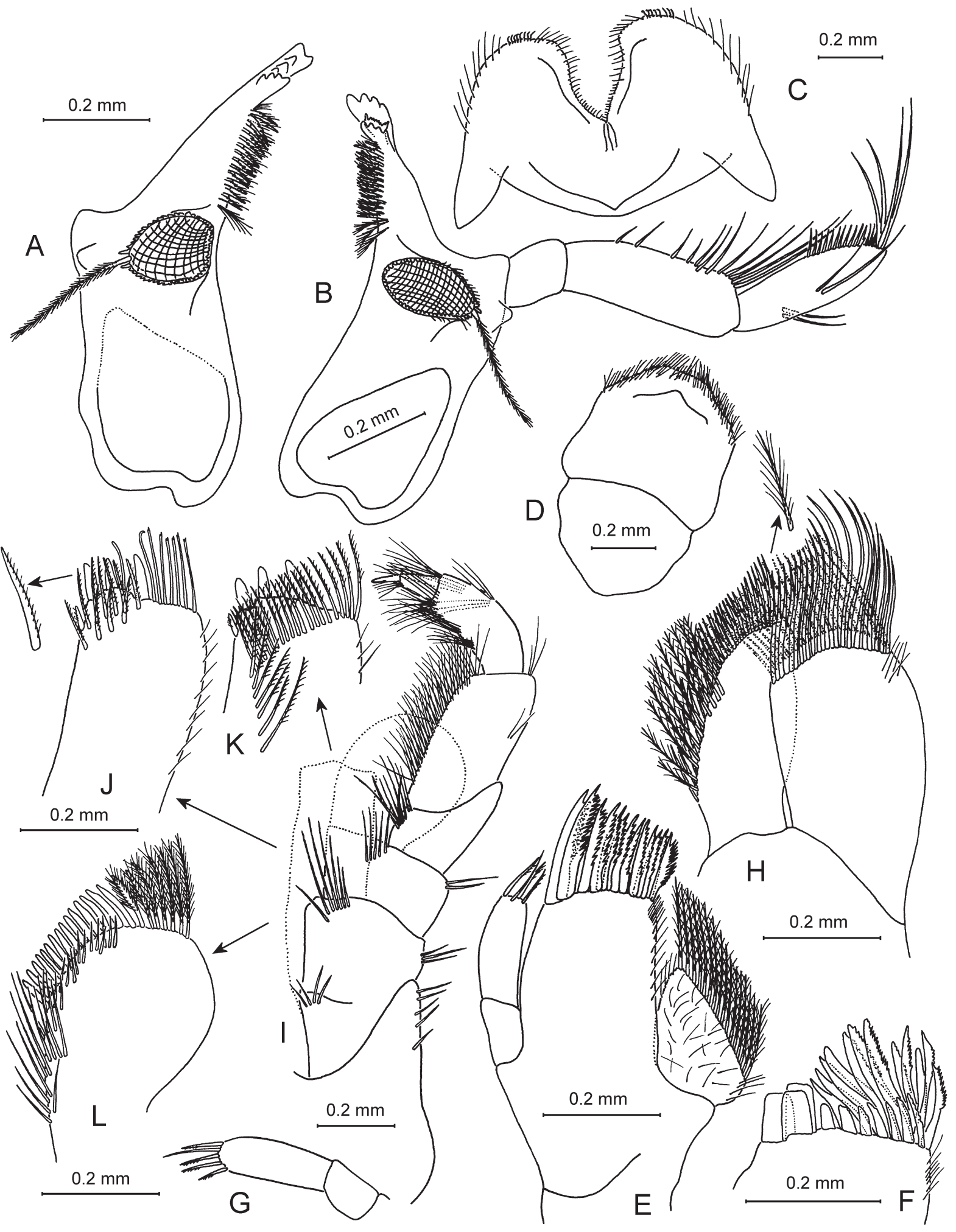

Fig. 8. Zenkevitchia sandroruffoi sp. nov. - A-E, G-K. Holotype, ô, 8.0 mm, X44041/Cr-1647-FEFU. A. Left mandible. B. Right mandible. C. Lower lip. D. Upper lip. E. Maxilla 1. G. Palp of right maxilla 1. H. Maxilla 2. I. Maxilliped. J. Inner plate of maxilliped, inner face. K. Inner plate of maxilliped, outer face. - F, L. Paratype,, , $8.3 \mathrm{~mm}$, X44043/Cr-1649-FEFU. F. Outer plate of maxilla 1. L. Outer plate of maxilliped. 


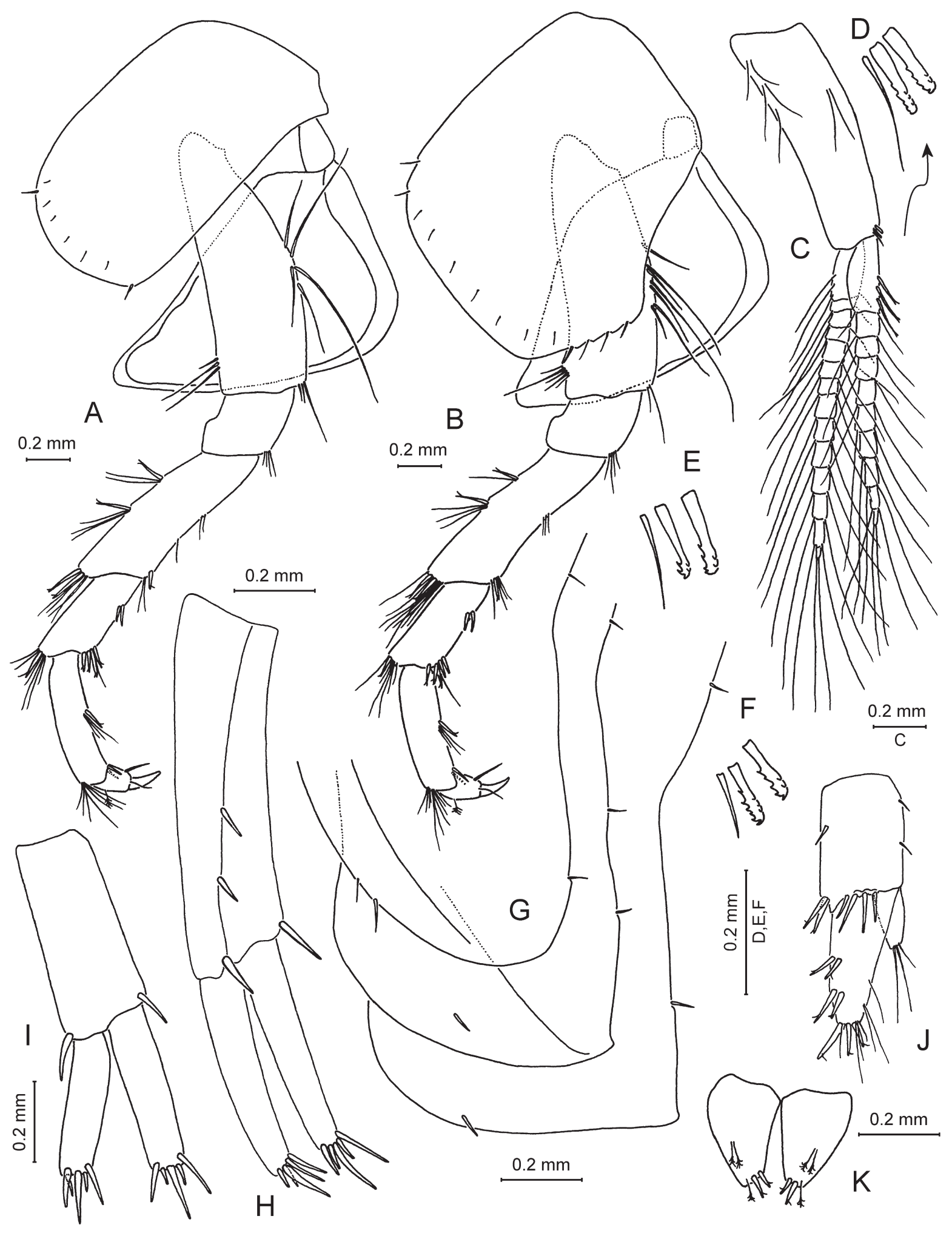

Fig. 9. Zenkevitchia sandroruffoi sp. nov. Holotype, $\widehat{\partial}, 8.0$ mm, X44041/Cr-1647-FEFU. A. Pereopod 3. B. Pereopod 4. C. Pleopod 1. D-F. Coupling setae of pleopods 1-3. G. Epimeral plates 1-3. H. Uropod 1. I. Uropod 2. J. Uropod 3. K. Telson. 


\title{
Description
}

\author{
Male (holotype)
}

BODY LENGTH. $8.0 \mathrm{~mm}$.

General Body morphology (Fig. 9G, K). Body smooth, with median and lateral, sparse, single setae, lacking dorsal cuticular elements but with distinct humps on pleonal segments. Head as long as first pereon segment; rostrum absent; inferior antennal sinus deep, rounded. Eyes absent. Urosomites 1-3 on dorsal surface with lateral spines and setae; armed with notched spines in the following manner: 1 $(0-0), 2$ (2-2), 3 (1-0-1). Epimeral plate 1: postero-ventral corner beveled; posterior and ventral margins convex; 2 stiff setae along ventral margin, 1 seta along posterior margin. Epimeral plate 2: posteroventral corner acuminate; posterior margin convex; ventral margin convex; 1 stiff seta along ventral margin, 2 setae along posterior margin. Epimeral plate 3: postero-ventral corner acuminate; posterior margin straight; ventral margin straight; 1 stiff seta along ventral margin, 1 seta along posterior margin. Telson: width:length ratio is 1:0.6; cleft entirely; 2 apical spines per lobe present, $0.3-0.4 \times$ telson length, each accompanied by 1 or 2 plumose setae.

Antennae (Figs 2, 7A-B). Antenna $10.38 \times$ of body length; main flagellum with up to 23 articles; each article with 5-9 short setae; peduncular articles in ratio 1:0.7:0.4; proximal article of peduncle distally with 1 medial set of long setae; accessory flagellum 3-articulated. Length ratio of antenna 1 to antenna 2 is 1:0.6; flagellum of antenna 2 with 10 articles, each article densely setose; length ratio of peduncle articles 4 and 5 is 1:0.8; flagellum $0.4 \times$ longer than peduncle (articles $4+5$ ); peduncular articles 4 and 5 with sets of long, stiff setae on lateral and medial faces; gland cone long, reaching half of peduncle of segment 4.

MOUTH PARTS. Typical gammarid, except for unusual maxilla 1 (Figs 4H, 8A-E, G-L). Labrum rounded, clypeus unfused, longer than broad. Inner lobes of labium absent, outer lobes broad with stiff curved setae marginally, mandibular process distinct (narrow). Left mandible: incisor with 5 teeth, lacinia mobilis with 4 teeth; between lacinia and molar a row of 14 serrate spines. Right mandible: incisor process with 4 teeth, lacinia mobilis bifurcate, with several small denticles, between lacinia and molar a row of 12 serrate spines; triturative molar process with long lanose seta. Mandibular palp article 2 slightly longer than article 3 (distal); proximal palp article without setae; second article with 12 setae; distal article narrowed, with 1 A group of 2 setae, 2 B setae, 13 D setae and 4 E setae. Maxilla 1 palp reduced, distal article with 4 or 5 apical setae (both palps sub-symmetrical); outer plate with 22 multi-toothed spines; inner plate triangular, with 16 plumose setae. Maxilla 2 inner plate smaller than outer one with, oblique row of 11 plumose setae; both of them apically with numerous setae in two rows. Maxilliped palp article 2 narrow, with about 55 setae along inner margin; article 3 narrow, with 2 dense sets of setae on inner face; article 4 (distal) with dorsal seta, bearing 5 setae at the nail base, nail shorter than pedestal; outer plate with 15 flattened naked spines and 7 long plumose setae on apex ( 3 of them flattened); inner plate with 3 strong spines ( 1 supplemental spine on medial face) and 8 stiff, naked setae on apex, 27 plumose setae on ventral face, 10 stiff denticulate setae in 2 rows on dorsal face. Foregut lateralia with 15 strong pectinate spines, with densely setose row of stiff setae.

Coxal plates, gills (Figs 7D-E, 9A-B, 10A-C). Coxal plate 1 of rectangular shape, antero-ventral margin extended, with 3 setae. Coxal plate 2 of rectangular shape, antero-ventral margin narrowed, with 3 setae. Coxal plate 3 width: depth is $0.5: 1$, along antero-ventral margin with 2 setae. Coxal plate 4 of sub-quadrate shape, width: depth is $0.9: 1$; posteriorly with prominent excavation, along ventral margin 6 setae. Coxal plates 5-7 progressively smaller towards the posterior. Coxal plates 5-6: only anterior lobe well-developed; posterior margin pointed with 2 setae. Coxal plate 7 sub-triangular, anterior part beveled, along posterior margin with 3 setae in shallow serration. Coxal gills 2-7 stalked, large but progressively smaller towards the posterior; gills 2-4 triangular, gills 5-7 saccular or irregularly ovoid. 
Gnathopods 1-2 (Figs 7D-G). Gnathopod 1: ischium with postero-distal set of 6 short setae. Carpus $0.4 \times$ length of basis and $0.56 \times$ length of propodus; anterior margin of carpus with 1 group of setae; carpus posteriorly with 2 sets of lateral setae. Propodus sub-rectangular, palm straight, with cutting margin smooth and shorter than posterior margin; along posterior margin 5 simple setae with 1 pair of notched spines; anterior margin with 2 sets of setae, antero-distal group with 4 setae; palmar margin with short, notched setae along outer and inner faces, palmar angle with a group of 4 distally-notched, strong

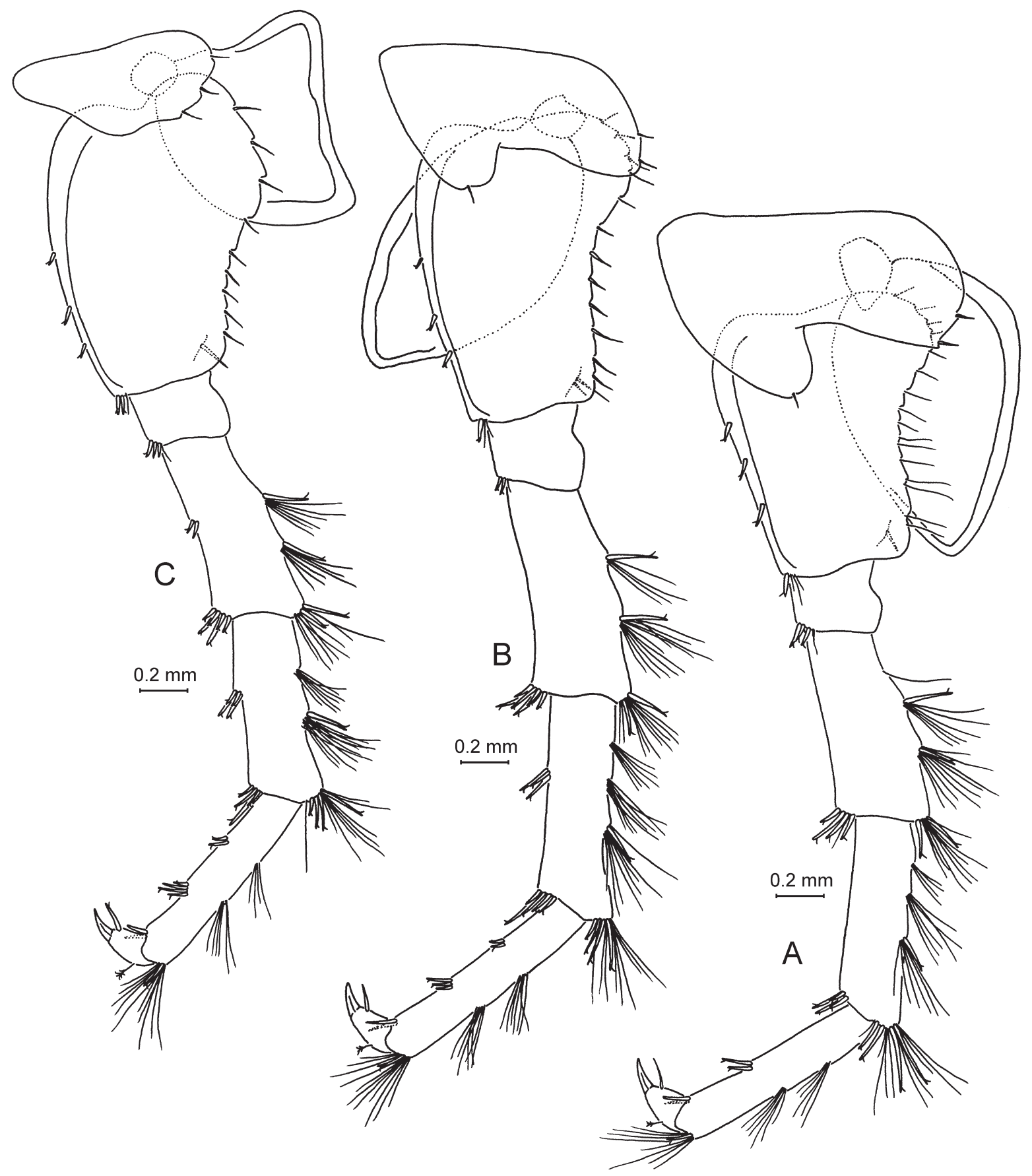

Fig. 10.Zenkevitchia sandroruffoi sp. nov. Holotype, ${ }^{\lambda}, 8.0$ mm, X44041/Cr-1647-FEFU. A. Pereopod 5. B. Pereopod 6. C. Pereopod 7. 
corner spines on both faces; nail long, $0.4 \times$ total length of dactylus, 1 seta along anterior margin and 3 setules at hinge. Gnathopod 2: basis width:length is $0.34: 1$. Ischium with 2 sets of postero-distal setae. Carpus $0.3 \times$ length of basis and $0.56 \times$ length of propodus; anterior margin of carpus with 1 distal set of setae; carpus posteriorly with 3 lateral sets of setae. Propodus small (compared to the body) and same length as propodus of gnathopod 1; propodus sub-rectangular, palm straight, with cutting margin smooth and shorter than posterior margin; posterior margin with 4 sets of stiff setae; anterior margin with 2 sets of setae; antero-distal group with 5 setae; palmar margin with short, notched setae along outer and inner faces, palmar angle with a group of 5 distally-notched, strong corner spines on both faces; dactylus similar to that of gnathopod 1.

Pereopods 3-7 (Figs 9A-B, 10A-C). Lengths of pereopods 3-4 equal. Dactylus $40.5 \times$ propodus 4; nail length $0.5 \times$ total dactylus length. Dactyli 3-4 with dorsal plumose seta; inner margin with 1 stiff seta and 1 thin seta at hinge. Lengths of pereopods 5:6:7 is 0.9:1:0.9. Pereopod 7 length $0.47 \times$ body length. Bases 5-7 narrowed distally; posterior margin with postero-proximal lobes; posteriorly marginal serrations with stiff setae (with thin setae in basis 5); anteriorly 3 notched spines. Dactylus 7 length $0.37 \times$ propodus 7 length. Dactyli 5-7 with dorsal plumose seta; inner margin with 1 stiff, notched seta and 1 thin seta at hinge.

Pleopods (Fig. 9C-F). Pleopods 1-3 sub-equal, each with 2 coupling setae accompanied by 1 stiff seta; peduncular articles fringed with long, thin setae; proximal article of inner rami fringed with 3 bifurcate setae. Pleopods 1-3 rami with 10-15 articles each.

UROPODS (Figs 2, 9H-J). Uropod 1 protopodite without basofacial spine, with 3 dorso-lateral spines and 1 dorso-medial spine; exopodite:endopodite length is $0.95: 1$; rami straight and unarmed along outer margins; both with 5 strong, notched spines apically and sub-apically. Uropod 2 exopodite slightly curved and $0.2 \times$ shorter than endopodite. Uropod 3 protopodite with 2 groups of strong notched spines on apex; endopodite $0.4 \times$ of protopodite length, with 3 long setae apically; exopodite $1.16 \times$ longer than protopodite, with 2 groups of lateral spines, long simple setae along inner margin, 3 spines and 4 setae apically.

Female (paratype X44043/Cr-1649-FEFU)

Body length $8.3 \mathrm{~mm}$, with sexually dimorphic characters (Fig. 11). Smaller than male, with more slender body. Antenna 2 slender, peduncular article 4 with bundle of long setae on distal margin. Gnathopods 1 and 2: bases slender, with densely setose posterior margin; propodi sub-similar, sub-rectangular, but propodus of gnathopod 2 larger than on gnathopod 1; palmar margins sub-transverse, palm straight, with cutting margin acanthaceous; nail very long, $0.5 \times$ total length of dactylus. Uropod 3 weakly armed; endopodite with 2 long setae apically. Telson with 1 spines per lobe. Oostegites 2-5 on gnathopod 2 and pereopods $3-5$, very broad, with marginal setae.

\section{Variability}

Flagellum of antenna 1 with 21-23 articles. Uropod 3 endopodite with 2-3 setae apically. One individual had an abnormal 2-articulated accessory flagellum. The population of $Z$. sandroruffoi $\mathrm{sp}$. nov. inhabiting streams in the Orlinoe Gnezdo cave differs slightly by having a smaller body size and further shortened antenna 1, but are otherwise indistinguishable.

\section{Ontogenetic variation}

Almost all adults presented with significantly threadbare (Fig. 8F) or broken spines on the outer plate of maxilla 1. Thus, the first three of the most powerful spines turned out to be broken off in almost of all of the specimens. 


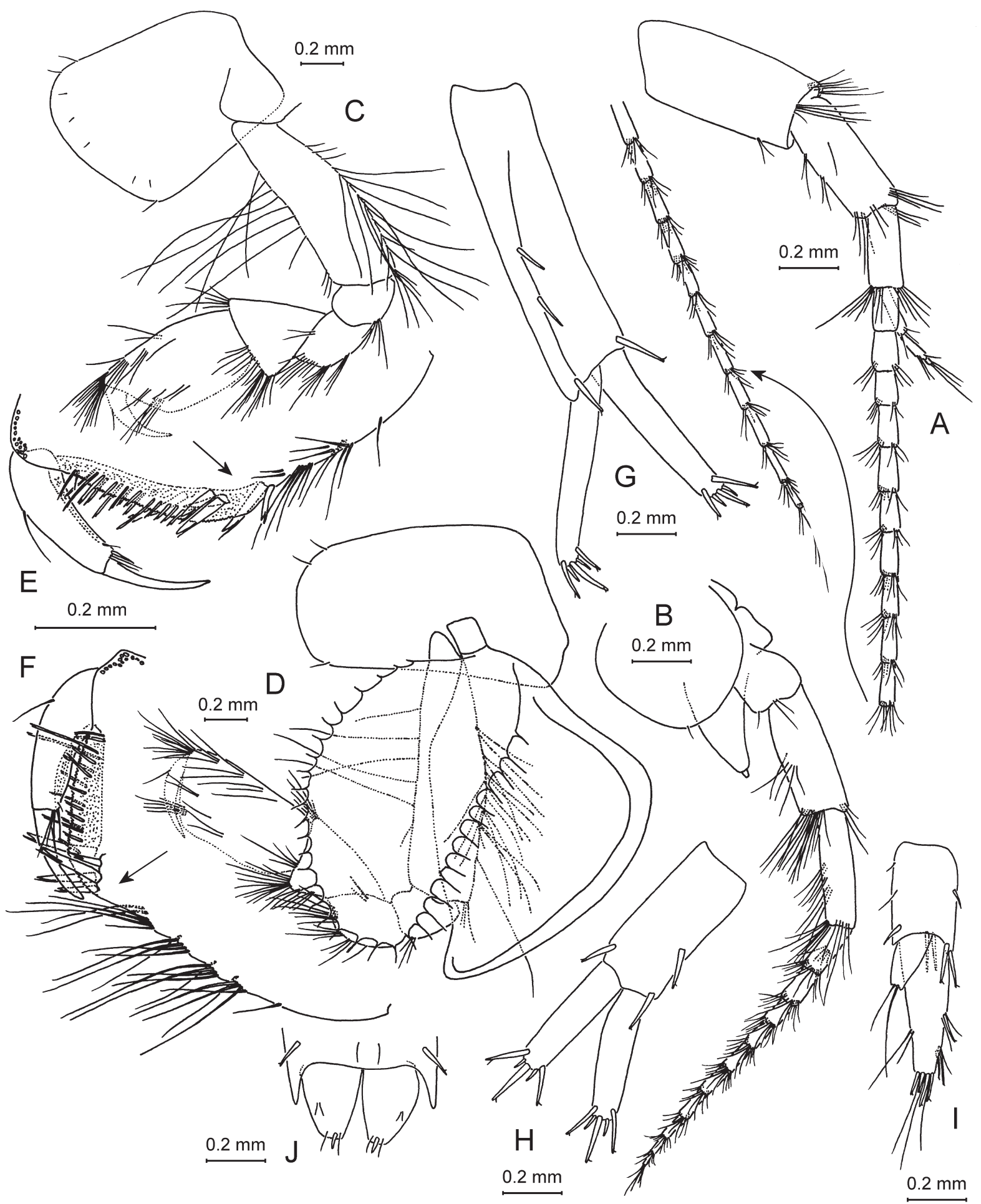

Fig. 11.Zenkevitchia sandroruffoi sp. nov. Paratype,, , 8.3 mm, X44043/Cr-1649-FEFU. A. Antenna 1. B. Antenna 2. C. Gnathopod 1. D. Gnathopod 2. E-F. Palmar margins of gnathopods 1 and 2 propodi. G. Uropod 1. H. Uropod 2. I. Uropod 3. J. Telson. 


\section{Distribution and ecology}

Zenkevitchia sandroruffoi sp. nov. inhabits aquatic biotopes in several caves (Fig. 1) in the Eastern Arabika massif and it apparently avoids deep cave habitats. This species was observed in the Sarma Cave not deeper than $-350 \mathrm{~m}$ (Fig. 2), in the nearby Trojka cave at a depth of $-30 \mathrm{~m}$ and in the notfar distant Orlinoe Gnezdo cave at $-75 \mathrm{~m}$. The setae on the antennal appendages of all specimens were densely covered (Fig. 7C) with attached filamentous algae (cyanobacteria?). The nature of the morphological variability and divergence of COI gene sequences (pairwise distances $<2.2 \%$ ) suggests that, in the Orlinoe Gnezdo cave, the other population of the same species is present.

Genus Adaugammarus gen. nov. urn:lsid:zoobank.org:act:C38A81BD-4918-46B0-BD37-4BF7A6669E8F

\section{Type species}

Adaugammarus pilosus sp. nov., by monotypy.

\section{Generic diagnosis}

Stout and gentle, large-sized species of gammarid-like habitus (sexual dimorphism marked, i.e., some males larger than females, antenna 2 , both gnathopods and uropods 1-3 sexually dimorphic). Antenna 1 short, reaching 50\% length of body; antenna 2 short, reaching about $50 \%$ length of antenna 1 , gland cone short. Maxilla 1 inner plate trapezoidal, with 10 plumose setae, outer plate of non-filtration type (?scraper type), with 14 multi-toothed, comb-like spines; palps asymmetric and long. Mandibular palp article 3 with 2 A groups, 2 B groups, 13 D setae and 4 E setae. Gnathopods 1-2 relatively small, with propodus not larger than corresponding coxa; palmar angles of both gnathopods undefined, each bearing a group of notched, strong palmar spines; dactyli with 1 seta along outer margin, nails rather long. Pereopods 5-7 bases distinctly broader in proximal part; inner margin of dactyli of pereopods 3-7 with 1 stiff seta. Urosomites with dorsolateral groups of spines. Pleopods 1-3 with 2 coupling setae (retinacula), each accompanied by 1 seta $(2+1)$. Uropods $1-3$ extremely setose, with dense bundles of long swirling setae; uropod 1 exopodite broad and curved; uropod 3 exopodite broad, $1.6 \times$ longer than protopodite (in males). Telson with 1 or 2 distal spines per lobe. Coxal gills $2-7$ stalked, triangular or sacciforme, largest on gnathopod 2, successively smaller on pereopods 3 to 7 , gill 7 the smallest. Body length $12.5-16.5 \mathrm{~mm}($ ( + +$), 11.5-17.5($ ふふ).

\section{Etymology}

The generic epithet (Adaugammarus) is derived by the combination of Adau, the name of fearsome malicious giants in Abkhazian mythology, with Gammarus, a closely related genus. Gender masculine.

\section{Discussion of affinities}

Adaugammarus gen. nov. is an interesting taxon possessing features typical for a number of groups, but tending more towards Typhlogammarus because of the following characters: lateral cephalic lobe with recess, propodi of both gnathopods with palmar angles undefined, uropod 3 exopodite distinctly broad in males. Adaugammarus gen. nov. is related to the sandroruffoi-group of Zenkevitchia and Typhlogammarus in the similar structure of the outer plate, which has 14 multi-toothed spines. The urosomal segments are armed in a similar manner to those of Zenkevitchia. Adaugammarus gen. nov. differs from Metohia in the absence of dorsal cuticular elements and from Accubogammarus in having a short antennal gland cone, in variramus uropod 3, and differs in having 14 multi-toothed spines on the outer plate of maxilla 1, in contrast to the 38 very densely toothed spines present in Accubogammarus. Superficial comparison with the other "deep dweller", cf. Zenkevitchia sp. sensu Jaume in Sendra \& Reboleira (2012) from the Krubera-Voronja cave, revealed that the two taxa differ significantly from each other by the body shape and by the extremely large body size $(\sim 19.0-28.0 \mathrm{~mm}$ in females from Krubera) (pers. obs.). 
Adaugammarus pilosus gen. et sp. nov. urn:1sid:zoobank.org:act:356488CF-429D-4F6D-AD07-2E04A8E659F1

Figs 2, 4I-K, 12-16

\section{Diagnosis (both sexes)}

As for the genus. A. pilosus gen. et sp. nov. is readily distinguished from the other cavernicolous typhlogammarids by the sexually dimorphic uropods. See the section 'Discussion of affinities' and the key below.

\section{Etymology}

The species epithet (pilosus, Latin), meaning "covered with hairs", refers to the extremely setose uropods in males.

\section{Material examined}

\section{Holotype}

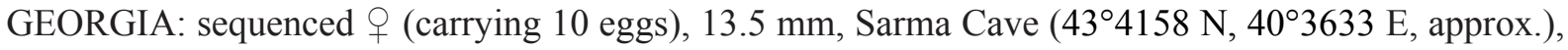
2346 m a.s.l., Transsib meander (sampling depth -1270 m), Arabika massif, Gagra District, Western Caucasus, 15 Sep. 2011, coll. P.V. Rudko (X44046/Cr-1652-FEFU).

\section{Paratypes}

GEORGIA: ${ }^{\lambda}, 11.5 \mathrm{~mm}$, ㅇ (oostegites developed, setose), $12.5 \mathrm{~mm}$, ( (carrying 21 eggs), $16.5 \mathrm{~mm}$, same data as holotype; $\widehat{O}, 17.5 \mathrm{~mm}$, Sarma Cave, pit K25 Vodoprovod, (sampling depth -1700 m), 21 Sep. 2011, coll. P.V. Rudko (X44047/Cr-1653-55-FEFU).

\section{Description}

\section{Holotype}

BODY LENGTH. $13.5 \mathrm{~mm}$.

General body morphology (Figs 2, 4I-J, 14C, G). Body smooth, with median and lateral thin setae, lacking dorsal cuticular elements (keel or tubercles). Head shorter than first pereon segment; rostrum indistinct; lateral cephalic lobe with recess; inferior antennal sinus shallow, sub-rounded. Eyes absent. Urosomites 1-3 on dorsal surface with lateral spines and setae; armed with notched spines in the following manner: 1 (0-0), 2 (1-1), 3 (1-0-1). Epimeral plate 1: postero-ventral corner prominent; posterior and ventral margins convex; 3 stiff setae along ventral margin, 5 setae along posterior margin. Epimeral plate 2: postero-ventral corner prominent; posterior margin straight; ventral margin convex; 3 stiff setae along ventral margin, 3 setae along posterior margin. Epimeral plate 3: postero-ventral corner prominent; posterior margin straight; ventral margin convex; 3 stiff setae along ventral margin, 1 seta along posterior margin. Telson: width: length ratio is $0.9: 1$; cleft 0.9 of length; 2 apical spines per lobe, each accompanied by 2 setae.

Antennae (Figs 2, 12A-B). Antenna $10.5 \times$ of body length; main flagellum with up to 34 articles; each article with 2-7 setae; peduncular articles in ratio 1:0.6:0.4; accessory flagellum 4-articulated. Length ratio of antenna 1 to antenna 2 is 1:0.5; flagellum of antenna 2 with 13 articles, each article densely setose; length ratio of peduncle articles 4 and 5 is $1: 0.9$; flagellum $0.2 \times$ longer than peduncle (articles $4+5$ ); peduncular articles 4 and 5 densely setose, with tight bundles of long stiff setae on lateral and medial faces; gland cone very short.

Mouth PARTS (typical gammarid, Figs 4K, 13). Labrum rounded, clypeus unfused, longer than broad. Inner lobes of labium absent, outer lobes broad, with stiff curved setae marginally, mandibular process distinct (narrow). Left mandible: incisor with 5 teeth, lacinia mobilis with 4 teeth; between lacinia and 
molar a row of 11 serrate spines. Right mandible: incisor process with 4 teeth, lacinia mobilis bifurcate, with several small denticles, between lacinia and molar a row of 9 serrate spines; triturative molar process with long plumose seta. Mandibular palp article 2 longer than article 3 (distal); proximal palp article without setae; second article with 21 setae; distal article narrowed, with 2 A groups of 2 and 7

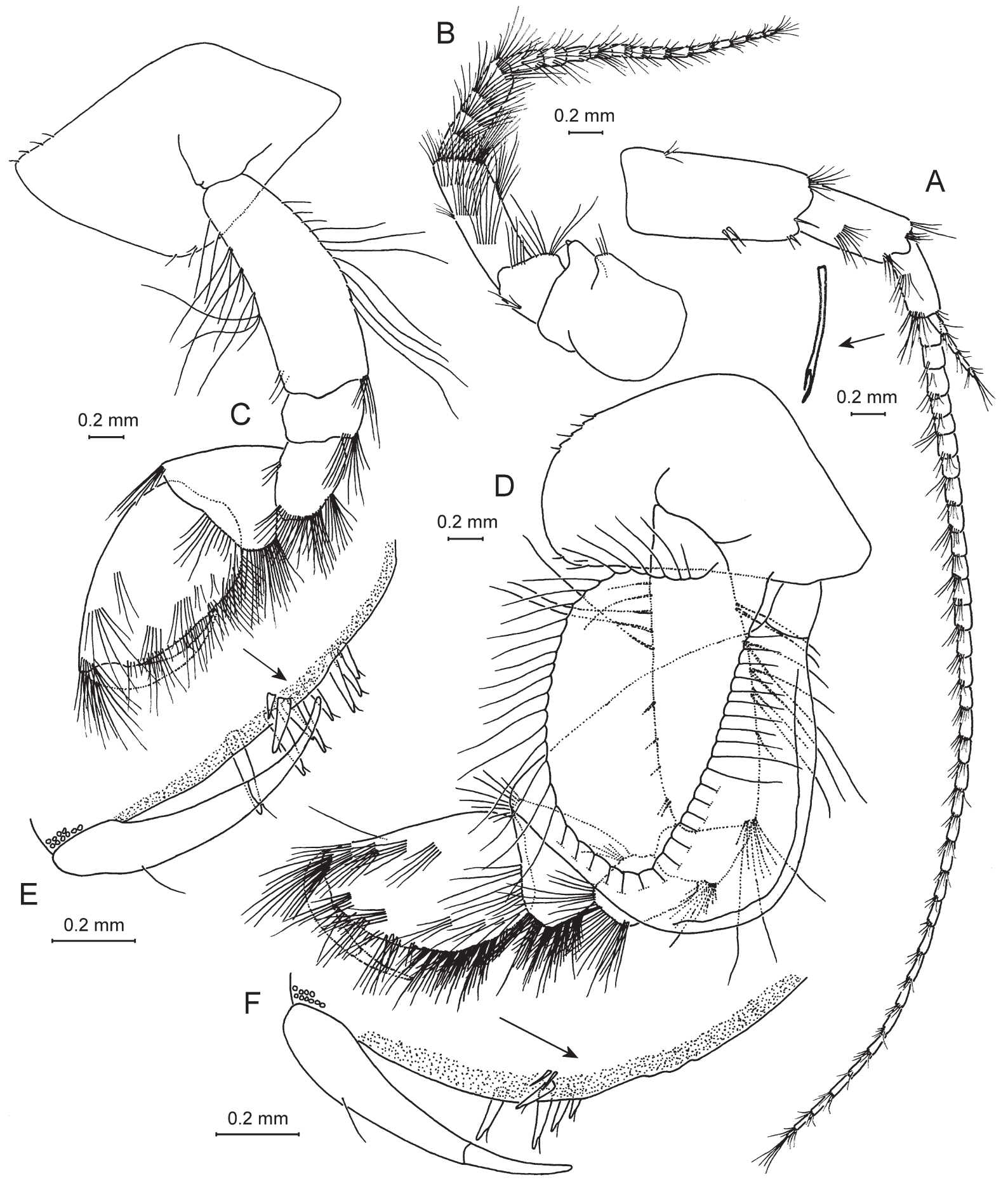

Fig. 12. Adaugammarus pilosus gen. et sp. nov. Holotype, $ᄋ, 13.5 \mathrm{~mm}, \mathrm{X} 44046 / \mathrm{Cr}-1652-\mathrm{FEFU}$. A. Antenna 1. B. Antenna 2. C. Gnathopod 1. D. Gnathopod 2. E-F. Palmar margins of gnathopods 1 and 2 propodi (setation omitted). 


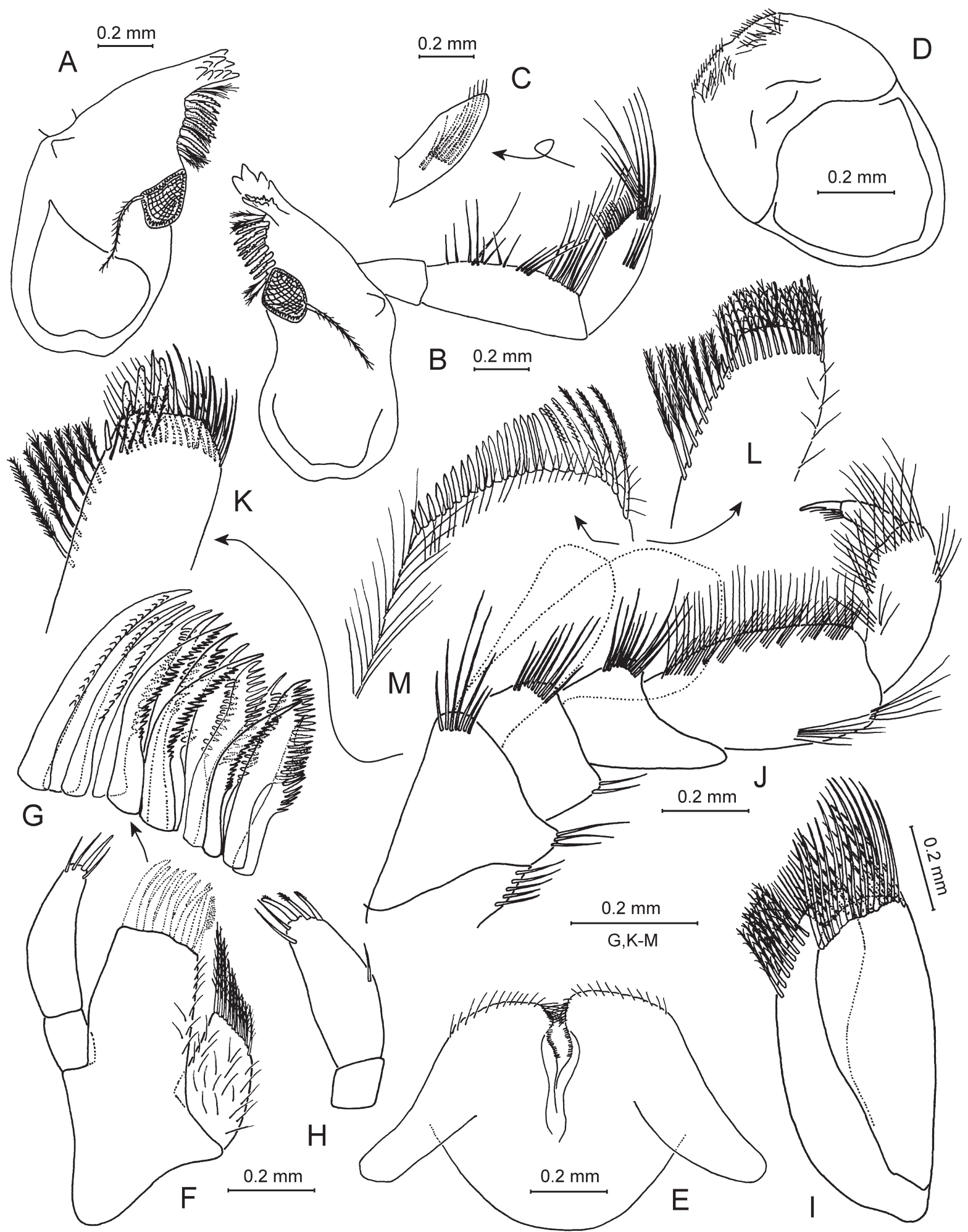

Fig. 13. Adaugammarus pilosus gen. et sp. nov. Holotype, $,+13.5 \mathrm{~mm}, \mathrm{X} 44046 / \mathrm{Cr}-1652-\mathrm{FEFU}$. A. Left mandible. B. Right mandible. C. Article 3 of mandibular palp, ventral setation. D. Upper lip. E. Lower lip. F. Maxilla I. G. Outer plate of maxilla 1. H. Palp of right maxilla 1. I. Maxilla 2. J. Maxilliped. K. Inner plate of maxilliped, inner face. L. Inner plate of maxilliped, outer face. M. Outer plate of maxilliped. 
setae, respectively, 2 B groups of 3 and 4 setae, respectively, 13 D setae and 4 E setae. Maxilla 1 palp long, distal article with 1 or 3 apical spines accompanied with setae (both palps asymmetric, right palp broader, with 1 seta on outer margin); outer plate with 14 multi-toothed spines; inner plate trapezoidal, with 10 plumose setae. Maxilla 2 with both plates narrowed, inner plate with oblique row of 8 plumose setae; both of them apically with numerous setae in two rows. Maxilliped palp article 2 broad, with

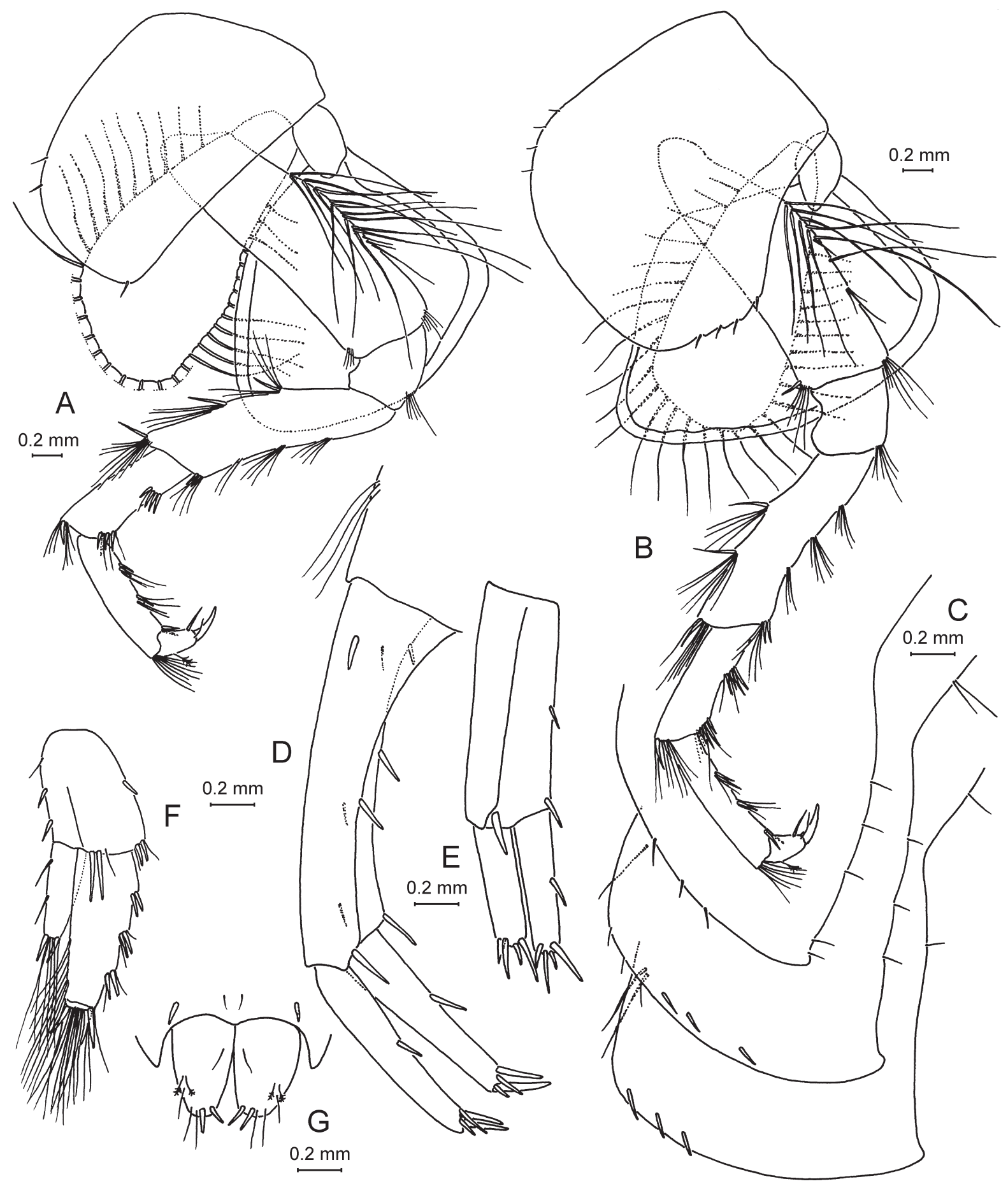

Fig. 14. Adangammarus pilosus gen. et sp. nov. Holotype, + , $13.5 \mathrm{~mm}, \mathrm{X} 44046 / \mathrm{Cr}-1652-\mathrm{FEFU}$. A. Pereopod 3. B. Pereopod 4. C. Epimeral plates 1-3. D. Uropod I. E. Uropod 2. F. Uropod 3. G. Telson. 


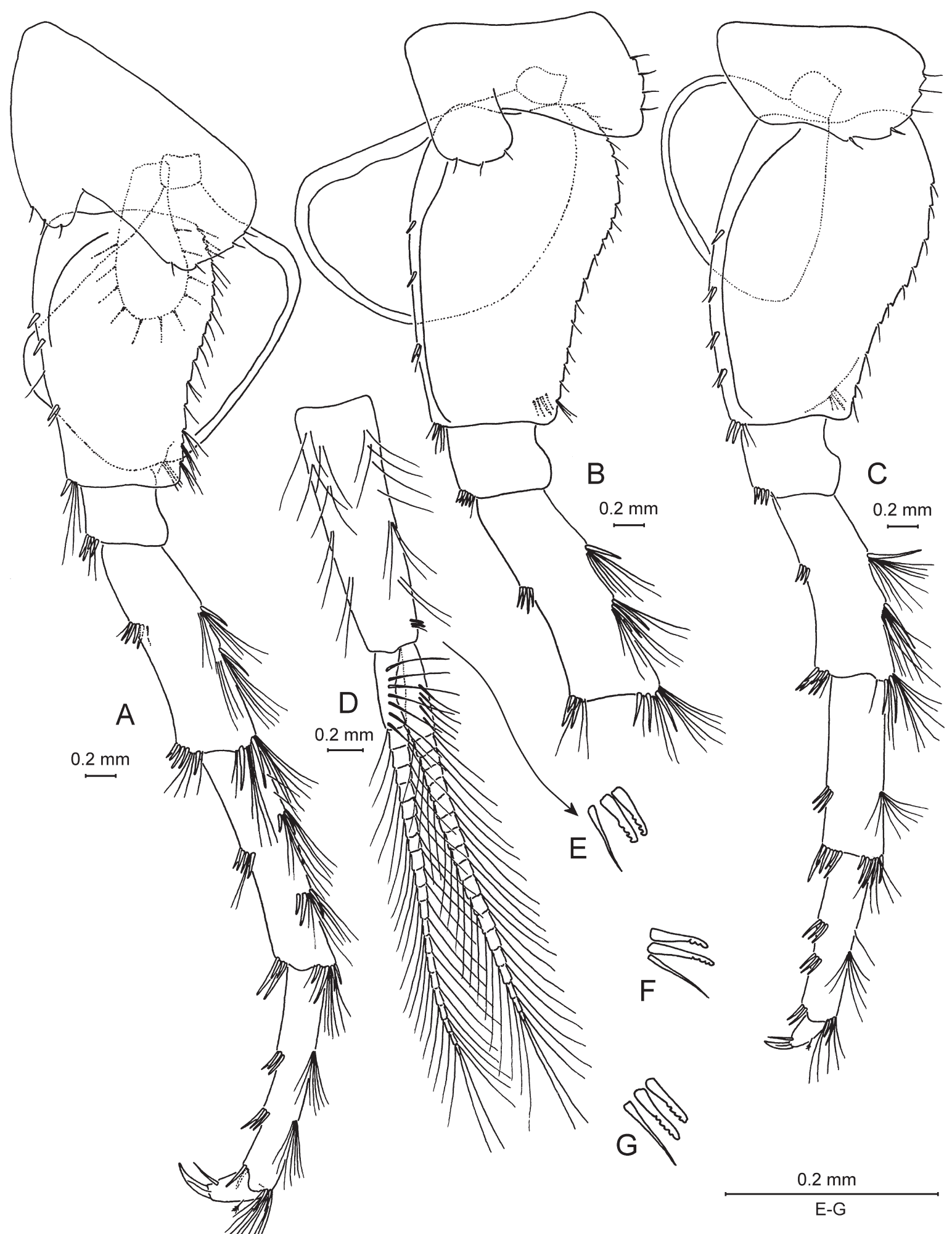

Fig. 15. Adaugammarus pilosus gen. et sp. nov. Holotype, $+, 13.5 \mathrm{~mm}, \mathrm{X} 44046 / \mathrm{Cr}-1652-\mathrm{FEFU}$. A. Pereopod 5. B. Pereopod 6, part. C. Pereopod 7. D. Pleopod 1. E-G. Coupling setae of pleopods 1-3. 
about 75 setae (some of them in 8 oblique clusters) along inner margin; article 3 narrow, densely setose, with long setae on inner face; article 4 (distal) with dorsal seta, bearing 5 setae at nail base, nail half as long as pedestal; outer plate with 18 flattened, naked spines, 2 long serrate spines and 3 long plumose setae on apex; inner plate with 3 strong spines (1 supplemental spine on medial face) and 13 stiff, naked setae apically and sub-apically, 24 plumose setae on ventral face, 5 stiff denticulate setae on dorsal face. Foregut lateralia with 17 strong pectinate spines, with densely setose row of stiff setae.

Coxal plates, gills and oostegites (Figs 12C-D, 14A-B, 15A-C). Coxal plate 1 of rectangular shape, antero-ventral margin extended, with sparse setae. Coxal plate 2 of sub-rectangular shape, antero-ventral margin narrowed with, sparse setae. Coxal plate 3 width: depth is $0.5: 1$, antero-ventral margin narrowed, with 3 setae. Coxal plate 4 of sub-quadrate shape, as long as broad; posteriorly with broad excavation; along ventral margin sparse setae. Coxal plates 5-7 progressively smaller towards the posterior; coxal plates 5-6 with anterior lobe well-developed; posterior margin pointed, with 4 or 5 setae. Coxal plate 7 sub-rectangular, along posterior margin 3 setae in shallow serration. Coxal gills 2-7 stalked, large but progressively smaller towards the posterior; gills 2-4 sub-triangular, gills 5-7 saccular or irregularly ovoid. Oostegites $2-5$ on gnathopod 2 and pereopods $3-5$, very broad, with long marginal setae.

Gnathopods 1-2 (Figs 12C-F). Gnathopod 1: ischium broadly setose, with stiff setae on distal and lateral margins. Carpus $0.36 \times$ length of basis and $0.4 \times$ length of propodus; anterior margin of carpus with 1 group of setae; carpus posteriorly with transverse row of lateral and marginal setae. Propodus almondshaped, palm convex, with cutting margin smooth and longer than posterior margin; along posterior margin a row of simple setae; anterior margin with 3 sets of setae, antero-distal group with 10 setae; palmar margin with short, notched setae along outer and inner faces, palmar angle undefined, a group of 10 distally-notched, strong spines on both faces (with 2 strong mid-palmar spines in the place where tip of nail close); nail long, $0.4 \times$ total length of dactylus, 1 seta along anterior margin, without setules at hinge. Gnathopod 2: basis width:length is $0.3: 1$. Ischium broadly setose, with stiff setae on distal and lateral margins. Carpus $0.27 \times$ length of basis and $0.4 \times$ length of propodus; anterior margin of carpus with 1 distal set of setae; carpus posteriorly with 5 lateral sets of setae and transverse row of marginal setae. Propodus small (compared to the body) and same length as propodus of gnathopod 1; propodus pyriform, palm convex with cutting margin smooth and shorter than posterior margin; posterior margin with 8 sets of stiff setae; anterior margin with 5 sets of setae; antero-distal group with 10 setae; palmar margin with short, notched setae along outer and inner faces, palmar angle undefined, a group of 5-6 distally-notched, strong spines on both faces in the place where tip of nail close (with 1 strong midpalmar spine); dactylus similar to that of gnathopod 1.

Pereopods 3-7 (Figs 14A-B, 15A-C). Lengths of pereopods 3-4 is $0.95: 1$. Dactylus $40.5 \times$ propodus 4; nail length $0.5 \times$ total dactylus length. Dactyli 3-4 with dorsal plumose seta; inner margin with 1 stiff seta and 1 thin seta at hinge. Lengths of pereopods $5: 6: 7$ is $0.9: 1: 0.9$. Pereopod 7 length $0.5 \times$ body length. Bases 5-7 narrowed distally; length:width is 1:0.5-0.6; posterior margin curved (distinctly in basis 7), without postero-distal lobes; marginal serrations with short setae posteriorly (expressed in basis 5); 3-4 notched spines anteriorly. Dactylus 7 length $0.28 \times$ of propodus 7 length. Dactyli $5-7$ with dorsal plumose seta; inner margin with 1 stiff seta and 1 thin seta at hinge.

Pleopods (Fig. 15D-G). Pleopods 1-3 sub-equal, each with 2 coupling setae accompanied by 1 stiff seta; peduncular articles fringed with long, thin setae; proximal article of inner rami fringed with 5 simple setae. Pleopods 1-3 rami with 19-21 articles each.

Uropods (Figs 2, 14D-F). Uropod 1 protopodite with 1 basofacial spine, 2 dorso-lateral spines and 3 dorso-medial spines; exopodite: endopodite length is $1: 0.8$; rami straight, with single spines along outer margins; both with 5 spines apically and sub-apically (two of them strong). Uropod 2 exopodite $0.2 \times$ 
shorter than endopodite. Uropod 3 protopodite with 2 groups of spines on apex; endopodite $0.7 \times$ of protopodite length, with 2 spines and 6 long setae apically; exopodite $1.3 \times$ longer than protopodite, with 3 groups of lateral spines, long simple setae along inner margin, 3 spines and about 13 setae apically.

\section{Male (paratype X44049/Cr-1655-FEFU)}

Body length $17.5 \mathrm{~mm}$, with sexually dimorphic characters (Fig. 16). Larger than female, with more stout body. Antenna 2 densely setose. Gnathopods 1 and 2 propodi sub-similar, almond-shaped, but propodus of gnathopod 2 larger than propodus of gnathopod 1; palmar margins beveled, palm straight, with

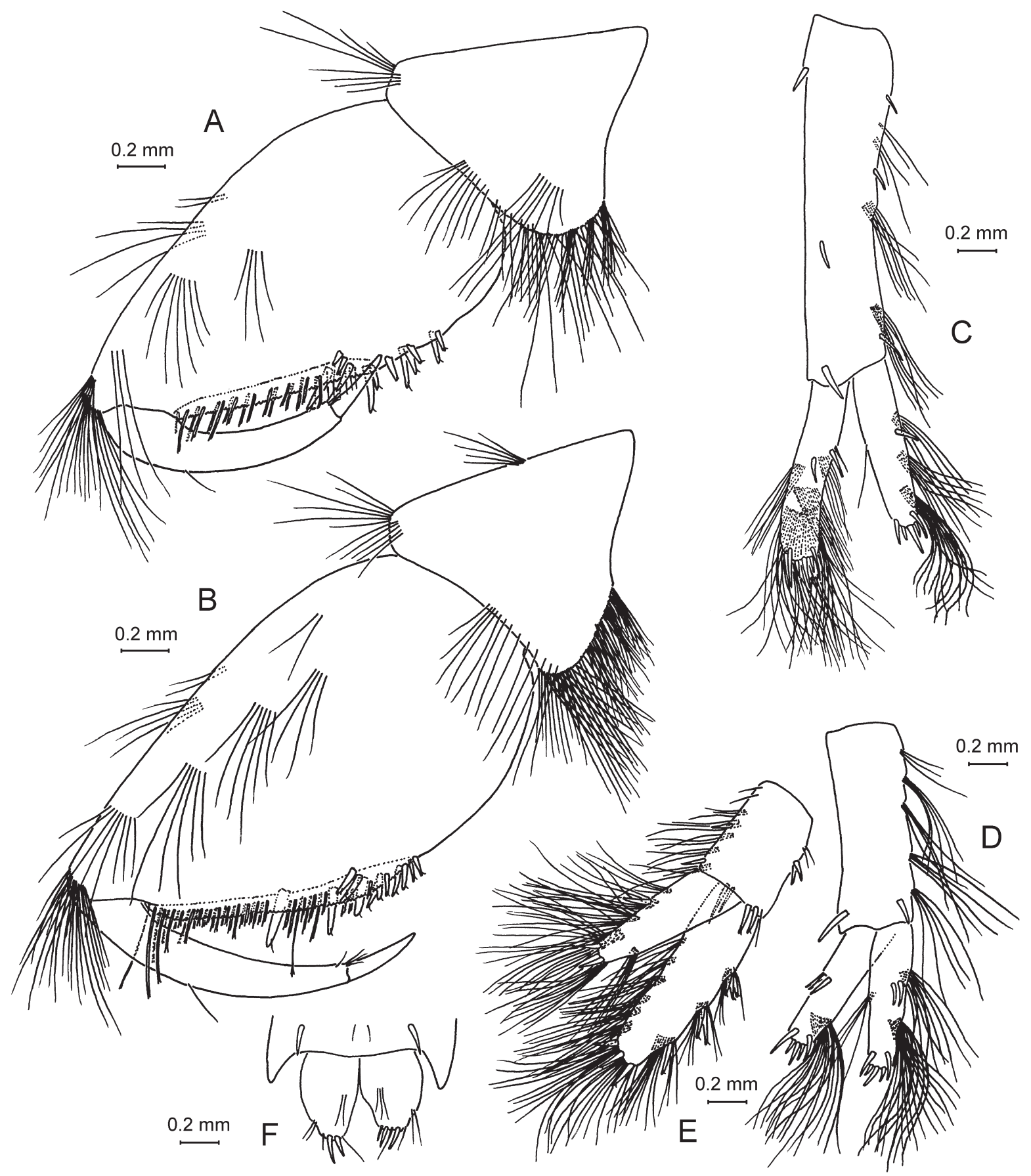

Fig. 16. Adaugammarus pilosus gen. et sp. nov. Paratype X44049/Cr-1655-FEFU, Ô, 17.5 mm. A. Gnathopod 1, part. B. Gnathopod 2, part. C. Uropod 1. D. Uropod 2. E. Uropod 3. F. Telson. 
Table 2. Estimates of pairwise sequence divergence (uncorrected p-distances) of partial mitochondrial COI gene among and within species (bold type) of the Balkan and Caucasian Typhlogammaridae. Numbers in brackets correspond to geographic locality on Fig. 1; $\mathrm{n} / \mathrm{a}=$ not applicable.

\begin{tabular}{lccccccccc}
\hline Species & $\begin{array}{c}\text { Number of } \\
\text { sequences }\end{array}$ & $\mathbf{1}$ & $\mathbf{2}$ & $\mathbf{3}$ & $\mathbf{4}$ & $\mathbf{5}$ & $\mathbf{6}$ & $\mathbf{7}$ & $\mathbf{8}$ \\
\hline 1. Zenkevitchia sandroruffoi $[1]$ & 6 & $\mathbf{0 . 0 0 3 4}$ & & & & & & \\
2. Adaugammarus pilosus [2] & 4 & 0.159 & $\mathbf{0 . 0 0 0 9}$ & & & & & & \\
3. Zenkevitchia yakovi [5] & 3 & 0.142 & 0.141 & $\mathbf{0 . 0 0 2 4}$ & & & & & \\
4. Metohia carinata & 1 & 0.245 & 0.235 & 0.237 & $\mathbf{n} / \mathbf{a}$ & & & & \\
5. Typhlogammarus mrazeki & 1 & 0.241 & 0.246 & 0.243 & 0.217 & $\mathbf{n} / \mathbf{a}$ & & & \\
6. Typhlogammarus sp. & 1 & 0.247 & 0.234 & 0.248 & 0.217 & 0.138 & $\mathbf{n} / \mathbf{a}$ & & \\
7. Zenkevitchia admirabilis $[4]$ & 2 & 0.138 & 0.150 & 0.128 & 0.239 & 0.233 & 0.247 & $\mathbf{0 . 0 7 8 3}$ & \\
8. Zenkevitchia revazi $[6]$ & 1 & 0.206 & 0.210 & 0.210 & 0.255 & 0.246 & 0.251 & 0.207 & $\mathbf{n} / \mathbf{a}$ \\
\hline
\end{tabular}

cutting margin acanthaceous; nail short, $0.3 x$ total length of dactylus. Uropods $1-3$ extremely setose. Uropod 1 protopodite with 3 sets of long setae along inner margin; exopodite broad and curved, longer than endopodite; rami setose, with dense bundles of long, swirling setae. Uropod 2 protopodite with 5 sets of long setae along inner margin; exopodite as long as endopodite; rami setose, with dense bundles of long, swirling setae. Uropod 3 protopodite with 5 sets of long setae along inner margin; endopodite $1.3 \times$ longer than protopodite, with 2 spines along inner margin and 2 spines on apex; exopodite broad, $1.6 \times$ longer than protopodite, with 3 groups of lateral spines, 3 spines on apex; rami setose, with dense bundles of long, swirling setae.

\section{Variability}

Not observed.

\section{Distribution and ecology}

Adaugammarus pilosus gen. et sp. nov. inhabits aquatic biotopes in the Sarma Cave (Figs 1-2) in the eastern Arabika massif (species was observed at depths of $-1270 \mathrm{~m}$ and $-1700 \mathrm{~m}$ ) and revealed an ability to move in a hygropetric zone.

\section{Phylogenetic analysis}

To access the affinities of the newly described taxa and confirm their genetic distinctness, we sequenced a partial mt-coxl gene from Z. sandroruffoi sp. nov. (6 accessions, Table 1) and Adaugammarus gen. nov. (4 accessions) and assembled a data set including their putative relatives, Accubogammarus, Metohia, Typhlogammarus, and Zenkevitchia spp. (Table 1). Specimens of Zenkevitchia sandroruffoi sp. nov. from the Trojka $(-30 \mathrm{~m}$ depth) and Sarma caves $(-350 \mathrm{~m})$ produced identical sequences (KT427522 and KT427521, respectively), as did two further specimens from the Orlinoe Gnezdo cave (-75 m; KT427523 and KT427524); the intraspecific distance is $0.34 \pm 0.17 \mathrm{SE}$ (Table 2). All four specimens of Adaugammarus pilosus gen. et sp. nov. from the deepest part of the Sarma Cave (-1270 to $-1700 \mathrm{~m}$; KT427516 - KT427519) were also almost identical in sequence; the intraspecific distance is $0.09 \pm 0.09$ SE (Table 2). Redundant sequences were excluded from the analyses. The resulting topology (Fig. 3) was generally in agreement with that previously obtained for a smaller data set (Sidorov et al. 2015). Species of Zenkevitchia were members of a clade (81\% BP) that also included Accubogammarus and Adaugammarus gen. nov. Topologically, $Z$. revazi was a basal divergence in this lineage. Adaugammarus gen. nov. was resolved as a sister (96\%) to a cluster composed of $Z$. sandroruffoi sp. nov., Z. admirabilis, and Z. yakovi. The branching pattern among these species remained unresolved. Four highly similar 
(p-distances $0.002-0.01) Z$. sandroruffoi formed a robust (100\%) clade characterized by a relatively long branch. Accessions from the Sarma and Trojka caves shared two synapomorphic substitutions and were clustered together to the exclusion of specimens from Orlinoe Gnezdo.

\section{Discussion}

\section{Brief observation on the vertical distribution of Amphipoda in the Sarma cave}

An integrated comparative morphological and genetic analysis of the new amphipod taxa in the Sarma Cave revealed their obvious dissimilarity, which in turn allows us to pay attention to the structure of this cave. The system of the Sarma Cave is heterogeneous in its physical structure. Following Burmak (unpubl.) there are three parts: upper, middle and lower. In the upper part, down to $-350 \mathrm{~m}, Z$. sandroruffoi sp. nov. was discovered; in the lower part, down to $-1700 \mathrm{~m}$, A. pilosus was present. In the middle part amphipods were not detected, but we can't exclude that they were overlooked. In the lower level (from $-900 \mathrm{~m}$ to $-1100 \mathrm{~m}$ ) in the zone of major faulting leading to the deepest part, the cave abruptly changes direction (see Fig. 2). In this part of the cave thick deposits of red clay are observed. There is also a strong flowing stream in this part of the cave.

Zenkevitchia sandroruffoi sp. nov. is not endemic to the Sarma Cave and was noted in two other caves. The most remote of the investigated caves, Orlinoe Gnezdo, is located about $3.5 \mathrm{~km}$ to the south of Sarma. This suggests that $Z$. sandroruffo $i$ sp. nov. is vagile, settling in suitable biotopes in the eastern Arabika massif. The affinity of $Z$. sandroruffoi sp. nov. to the Zenkevitchia lineage and its limited distribution suggest a relatively young phylogenetic age of this species. In contrast, A. pilosus is, in our view, morphologically closer to Typhlogammarus and hence its cohabitation with $Z$. sandroruffoi sp. nov. in the same cave at different depths is apparently not a result of parapatric speciation. Although there are no reliable data about the geophysical structure and history of the Sarma Cave, it seems that the lower part of the cave belongs to another speleological system, probably older than the overlying cave system.

\section{Key to the genera of Typhlogammaridae}

1 Pleosomal (abdominal) segments 1-3 with a pair of bilateral teeth dorsally ....Metohia Absolon, 1927

- Pleosomal segments without teeth ............................................................

2 Uropods in males setose with bundles of stiff, long setae ..............Adaugammarus gen. nov.

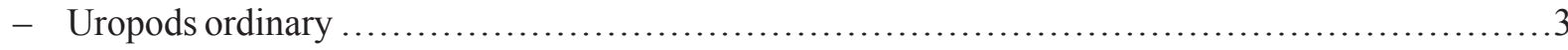

3 Antennal gland cone short ..................................Typhlogammarus Schäferna, 1907

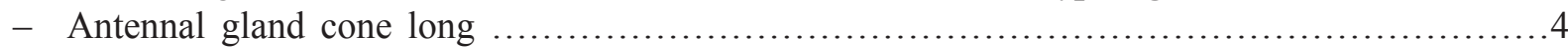

4 Maxilla 1 outer plate filtrative, multisetose ..................... Zenkevitchia (admirabilis-group)

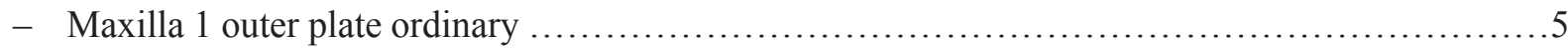

5 Uropod 3 parviramous, with inner ramus half as long as outer ramus

- Uropod 3 almost aequiramous, with inner ramus somewhat shorter

Zenkevitchia (sandroruffoi-group) Accubogammarus G. Karaman, 1974

\section{Acknowledgements}

The authors are thankful to our fellow cavers Pavel Rudko, Lyasan Kharlamova (Siberian Federal University, Krasnoyarsk) and Elena Golubnichaya (Vladivostok Caving Club) for collection of material during the research expeditions "Arabika-2011" and "Arabika-2012", to Dmitry Palatov (Moscow 
State University) for collecting specimens of Anopogammarus and forwarding samples to us, to Dr. T. Krapp-Schickel (Zoologisches Forschungsmuseum Alexander Koenig, Bonn) for providing DAS with literature, and to Dr. B. Sket (University of Ljubljana) and two anonymous reviewers for critically reading and commenting on the manuscript. This study was supported by the Russian Foundation for Basic Research project No. 15-54-40011Abh_a.

\section{References}

Absolon Ch. 1927. Les grandes amphipodes aveugles dans les grottes balkaniques. Comptes rendues du Congrès de Constantine, Association Française pour l'Avancement des Sciences, Paris 51: 290-295.

Barjadze S., Murvanidze M., Arabuli T., Mumladze L., Pkhakadze V., Djanashvili R. \& Salakaia M. 2015. Annotated List of Invertebrates of the Georgian Karst Caves. Georgian Academic Book, Tbilisi.

Barnard J.L. \& Barnard C.M. 1983. Freshwater Amphipoda of the World. Vols 1, 2. Mt. Vernon, Hayfield Associates, Virginia.

Barnard J.L. \& Karaman G.S. 1980. Classification of gammarid Amphipoda. Crustaceana, Supplement 6: 5-16.

Birstein J.A. 1940. Biospeologica Sovietica 3. Ueber die Fauna der Höhlenamphipoden Abchasiens. Bulletin of the Moscow Society of Naturalists, Biological Series 49: 47-55.

Birstein J.A. 1941. The subterranean amphipods of Abkhazia with notes on the Niphargus-species of Transkaukasus. Archives du Musée Zoologique de l'Université de Moscou 6: 259-272. [in Russian, with English summary]

Birstein J.A. 1950. Peshchernaya fauna Zapadnogo Zakavkazya. Zoologichesky Zhurnal 29: 354-366. [in Russian]

Birstein J.A. \& Ljovuschkin S.I. 1967. Some results and problems in studying of the subterranean fauna of the U.S.S.R. Zoologichesky Zhurnal 46: 1509-1535. [in Russian, with English summary]

Birstein J.A. \& Ljovuschkin S.I. 1970. Biospeologica Sovietica 41. Genera of Amphipoda endemic for Transcaucasus. Zoologichesky Zhurnal 49: 1471-1487. [in Russian, with English summary]

Birstein J.A. \& Lopaschov G.W. 1940. Biospeologica Sovietica 1. Erforschungen der Höhlenfauna der USSR in den Jahren 1935-1939. Bulletin of the Moscow Society of Naturalists, Biological series 49: 29-38.

Bonfield J.K., Smith K.F. \& Staden R. 1995. A new DNA sequence assembly program. Nucleic Acids Research 24: 4992-4999. http://dx.doi.org/10.1093/nar/23.24.4992

Bousfield E.L. 1977. A new look at the systematics of gammaroidean amphipods of the world. Crustaceana, Supplement 4: 282-316.

Bousfield E.L. 1978. A revised classification and phylogeny of amphipod crustaceans. Transactions of the Royal Society of Canada, Series 4 16: 343-390.

Burmak I.N. (unpubl.) The Sarma Cave: Description of the Speleo System. Unpublished.

Coleman C.O. 1991. Comparative fore-gut morphology of Antarctic Amphipoda (Crustacea) adapted to different food sources. Hydrobiologia 223: 1-9. http://dx.doi.org/10.1007/BF00047623

Derzhavin A.N. 1945. The subterranean Amphipoda of Transcaucasus. Bulletin of the Academy of Sciences of Azerbaijan SSR 8: 27-43. [in Russian, with English summary]

Dublyansky B.H., Klimchuk A.B., Kiselev V.E., Vahrushev B.A., Kovalev Yu.N., Melnikov V.P., Ryzhkov A.F., Tintilozov Z.K., Chujkov V.D. \& Churubrova M.L. 1987. Krupnye karstovye polosti SSSR. 3. Speleologicheskie provincii Bolshogo i Malogo Kavkaza. VINITI, Moscow. [in Russian] 
SIDOROV D.A. et al., New genus and species of Typhlogammaridae

Felsenstein J. 1985. Confidence limits on phylogenies: an approach using the bootstrap. Evolution 39: 783-791. http://dx.doi.org/10.2307/2408678

Folmer O., Black M., Hoeh R., Lutz R. \& Vrijenhoek R. 1994. DNA primers for amplification of mitochondrial cytochrome $c$ oxidase subunit I from diverse metazoan invertebrates. Molecular Marine Biology and Biotechnology 3: 294-299.

Gorodkov K.B. 1961. The simplest microprojector for drawing insects. Entomological Review 40: 936939. [in Russian, with English summary]

Hou Z., Sket B. \& Li S. 2014. Phylogenetic analyses of Gammaridae crustacean reveal different diversification patterns among sister lineages in the Tethyan region. Cladistics 30: 352-365. http:// dx.doi.org/10.1111/cla.12055

Jordana R., Baquero E., Reboleira S. \& Sendra A. 2012. Reviews of the genera Schaefferia Absolon, 1900, Deuteraphorura Absolon, 1901, Plutomurus Yosii, 1956 and the Anurida Laboulbène, 1865 species group without eyes, with the description of four new species of cave springtails (Collembola) from Krubera-Voronya cave, Arabika Massif, Abkhazia. Terrestrial Arthropod Reviews 5: 35-85. http:// dx.doi.org/10.1163/187498312X622430

Karaman G.S. 1970. Beitrag zur Kenntnis der Amphipoden 25. Kritische Bemerkungen über Echinogammarus acarinatus (S. Kar. 1931) und Echinogammarus stocki n. sp. Poljoprivreda $i$ Šumarstvo 16: 45-66.

Karaman G.S. 1972. Contribution to the knowledge of the Amphipoda 38. On the genus Typhlogammarus (Schaferna) (fam. Gammaridae) from Yugoslavia. Fragmenta Balcanica, Musei Macedonici Scientarium Naturalium 9: 21-34.

Karaman G.S. 1973. Contribution to the knowledge of the Amphipoda 48. Two new species of Family Gammaridae from Yugoslavia, Niphargus deelemanae n. sp. and Typhlogammarus algor n. sp. Archiv für Hydrobiologie 72: 490-500.

Karaman G.S. 1974. Contribution to the knowledge of the Amphipoda 57. Genus Metohia Abs. in Yugoslavia and its relation to the genera Typhlogammarus Schaf. and Accubogammarus n. gen. Poljoprivreda i Šumarstvo 20: 43-57.

Karaman G.S. 1988. Contribution to the knowledge of the Amphipoda 167. The genus Accubogammarus G. Kar. in Yugoslavia with remarks to the genus Typhlogammarus Schaf. (Fam. Gammaridae). Poljoprivreda i Šumarstvo 34: 63-77.

Karaman G.S. \& Barnard J.L. 1979. Classificatory revisions in gammaridean Amphipoda (Crustacea), part 1. Proceedings of the Biological Society of Washington 92: 106-165.

Karaman G.S. \& Ruffo S. 1995. Sinogammarus troglodytes n. gen. n. sp. A new troglobiont Gammarid from China (Crustacea Amphipoda). International Journal of Speleology 23: 157-171.

Keane T.M., Creevey C.J., Pentony M.M., Naughton T.J. \& McInerney J.O. 2006. Assessment of methods for amino acid matrix selection and their use on empirical data shows that ad hoc assumptions for choice of matrix are not justified. BMC Evolutionary Biology 6: 29. http://dx.doi.org/10.1186/14712148-6-29

Marin I. \& Sokolova A. 2014. Redescription of the stygobitic shrimp Troglocaris (Xiphocaridinella) jusbaschjani Birštein, 1948 (Decapoda: Caridea: Atyidae) from Agura River, Sochi, Russia, with remarks on other representatives of the genus from Caucasus. Zootaxa 3754: 277-298. http://dx.doi. org/10.11646/zootaxa.3754.3.3

Ruffo S. 1995. Un nuovo gammaride cavernicolo dell'Albania (Albanogammarus inguscioi $\mathrm{n}$. gen. $\mathrm{n}$. sp.). Bollettino del Museo Civico di Storia Naturale di Verona 19: 443-452. 
Schäferna K. 1907. O novém slepém blešivci Typhlogammarus, n. sbg. Věstník Královské České Společnosti Náuk, Trída Mathemâticko-Prírodovedecká, Praha 26: 1-25.

Sendra A. \& Reboleira A.S.P.S. 2012. The world's deepest subterranean community - KruberaVoronja Cave (Western Caucasus). International Journal of Speleology 41: 221-230. http://dx.doi. org/10.5038/1827-806X.41.2.9

Sidorov D.A., Gontcharov A.A., Palatov D.M., Taylor S.J. \& Semenchenko A.A. 2015. Shedding light on a cryptic cavernicole: A second species of Zenkevitchia Birstein (Crustacea: Amphipoda: Typhlogammaridae) discovered via molecular techniques. Subterranean Biology 15: 37-55. http:// dx.doi.org/10.3897/subtbiol.15.4872

Sidorov D.A., Kharlamova L.T., Golubnichaya E.E., Rudko P.V. \& Sukhachev V.V. 2014. Preliminary data on biodiversity and distribution of troglobionts from caves of the Eastern Arabika massif Treugol'nik region (Western Caucasus), with special emphasis on the Sarma Cave. In: Gunko A.A., Dolotov Yu.A., Gaifutdinov A.M, Filippov A.G., Chervyatsova O.Ya., Kosarev M.N., Garshin D.I., Markov A.V., Parise M., Shaginyan S.M., Bahtadze N.A., Potapov S.S., Mavlyudov B.R., Zhitenev V.S., Trofimova E.V., Ridush B.T., Gunko O.G. (eds) Speleology and Spelestology. Proceedings of the 5th International Scientific Conference to the Centenary of A.V. Ryumin's Birth: 300-303. NISPTR, Naberezhnye Chelny.

Sket B. 2004. The cave hygropetric - a little known habitat and its inhabitants. Archiv für Hydrobiologie 160: 413-425. http://dx.doi.org/10.1127/0003-9136/2004/0160-0413

Stock J.H. 1973. The existence of interstitial members of the Gammarus-group (Amphipoda). Crustaceana 24: 339-341. http://dx.doi.org/10.1163/156854073X00731

Stock J.H. 1974. The systematics of certain Ponto-Caspian Gammaridae (Crustacea, Amphipoda). Mitteilungen aus dem Hamburgischen Zoologischen Museum und Institut 70: 75-95.

Tamura K., Stecher G., Peterson D., Filipski A. \& Kumar S. 2013. MEGA6: Molecular Evolutionary Genetics Analysis version 6.0. Molecular Biology and Evolution 30: 2725-2729. http://dx.doi. org $/ 10.1093 / \mathrm{molbev} / \mathrm{mst} 197$

Vinarski M.V., Palatov D.M. \& Glöer P. 2014. Revision of 'Horatia' snails (Mollusca: Gastropoda: Hydrobiidae sensu lato) from South Caucasus with description of two new genera. Journal of Natural History 48: 2237-2253. http://dx.doi.org/10.1080/00222933.2014.917210

Watling L. 1989. A classification system for crustacean setae based on the homology concept. In: Falenhauer B. \& Watling L. (eds) Functional Morphology of Feeding and Grooming in Crustacea. Crustacean Issues 6: 15-26.

Manuscript received: 25 September 2015

Manuscript accepted: 17 November 2015

Published on: 24 December 2015

Topic editor: Rudy Jocqué

Desk editor: Kristiaan Hoedemakers

Printed versions of all papers are also deposited in the libraries of the institutes that are members of the EJT consortium: Muséum national d'Histoire naturelle, Paris, France; Botanic Garden Meise, Belgium; Royal Museum for Central Africa, Tervuren, Belgium; Natural History Museum, London, United Kingdom; Royal Belgian Institute of Natural Sciences, Brussels, Belgium; Natural History Museum of Denmark, Copenhagen, Denmark. 